\title{
Article \\ Determination of Oxaliplatin by a UHPLC-MS/MS Method: Application to Pharmacokinetics and Tongue Tissue Distribution Studies in Rats
}

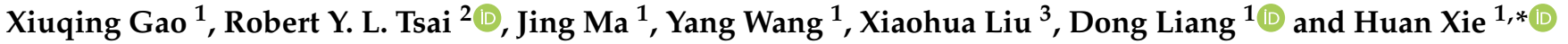 \\ 1 Department of Pharmaceutical Science, College of Pharmacy and Health Sciences, Texas Southern University, \\ Houston, TX 77004, USA; xiuqing.gao1990@gmail.com (X.G.); jing.ma@tsu.edu (J.M.); \\ yang.wang@tsu.edu (Y.W.); dong.liang@tsu.edu (D.L.) \\ 2 Department of Translational Medical Sciences, Institute of Biosciences and Technology, Texas A\&M Health \\ Science Center, Houston, TX 77030, USA; robtsai@tamu.edu \\ 3 Department of Biomedical Sciences, Baylor College of Dentistry, Dallas, TX 75246, USA; xliu1@tamu.edu \\ * Correspondence: huan.xie@tsu.edu; Tel.: +1-713-313-4340
}

check for updates

Citation: Gao, X.; Tsai, R.Y.L.; Ma, J.; Wang, Y.; Liu, X.; Liang, D.; Xie, H. Determination of Oxaliplatin by a UHPLC-MS/MS Method:

Application to Pharmacokinetics and Tongue Tissue Distribution Studies in Rats. Pharmaceuticals 2022, 15, 52. https://doi.org/10.3390/ph15010052

Academic Editors: Luisa Barreiros and Marcela Segundo

Received: 1 November 2021 Accepted: 29 December 2021 Published: 31 December 2021

Publisher's Note: MDPI stays neutral with regard to jurisdictional claims in published maps and institutional affiliations.

Copyright: (C) 2021 by the authors. Licensee MDPI, Basel, Switzerland. This article is an open access article distributed under the terms and conditions of the Creative Commons Attribution (CC BY) license (https:// creativecommons.org/licenses/by/ $4.0 /)$.

\begin{abstract}
Oxaliplatin (OXP), a third-generation platinum-based chemotherapy drug, was often indirectly analyzed via total platinum by an ICP-MS because it was difficult to directly quantify using an LC-MS/MS method, due to its instability, bad column separability and severe MS signal inhibition. Here, we developed and validated a specific, sensitive and reproducible LC-MS/MS method for the quantification of OXP itself in rat plasma and tongue tissue on a SCIEX 4000 QTRAP ${ }^{\circledR}$ MS/MS system equipped with a Phenomenex Lux 5 u Cellulose- 1 column $(250 \times 4.6 \mathrm{~mm}, 5 \mu \mathrm{m})$. This method was validated at the lower limit of detection (LOD) and the lower limit of quantitation (LLOQ) of $5 \mathrm{ng} / \mathrm{mL}$ and $10 \mathrm{ng} / \mathrm{mL}$, with linearity of $10-5000 \mathrm{ng} / \mathrm{mL}\left(\mathrm{r}^{2}>0.99\right)$ and $10-2500 \mathrm{ng} / \mathrm{mL}\left(\mathrm{r}^{2}>0.99\right)$, in rat plasma and tongue homogenates, respectively. The intra- and inter-day precision (CV\%) and accuracy (RE\%) were within 15\% for LLOQ, low-, medium- and high-quality control samples. The mean extraction recoveries were around $50 \%$ and $80 \%$ for plasma and tongue homogenates, respectively. This assay was successfully applied to pharmacokinetics study following intravenous administration of OXP, as well as tongue tissue distribution after $1 \mathrm{~h}$ and $4 \mathrm{~h}$ of a novel oral mucosal patch application.
\end{abstract}

Keywords: oxaliplatin; LC-MS/MS; plasma; tongue tissue; intravenous administration; pharmacokinetics

\section{Introduction}

Oxaliplatin (OXP, brand name Eloxatin ${ }^{\circledR}$, Figure 1) is a third-generation platinumbased antineoplastic drug widely used for solid tumor treatment in the clinic. It is an analogue of cisplatin by substituting the amino group of cisplatin with diaminocyclohexane (DACH). It was discovered in 1976, and approved by European Medicines Agency (EMA) in 1996 and the U.S. Food and Drug Administration (FDA) in 2002 [1]. Currently, OXP is typically used along with 5-fluorouracil and folinic acid (leucovorin) in a combination known as FOLFOX, a first-line treatment for stage III colorectal cancers. It shows higher anti-tumor activity and less toxicity as compared to cisplatin and carboplatin, due to its 1,2-DACH carrier ligand [2]. Recent studies showed that OXP had strong synergistic inhibition effects on oral squamous cell carcinoma (OSCC-25) cells when used along with mycophenolic acid, making OXP a potential candidate for treating oral precancerous lesions [3,4].

Like previous two generations of platinum-containing drugs, OXP also rapidly forms a variety of reactive intermediates after intravenous administration in vivo [5]. It undergoes rapid and extensive non-enzymatic biotransformation and has no evidence of being metabolized by cytochrome P450 [6]. In patients, there are at least 17 biotransformed products of 
OXP by reaction with water, chloride, glutathione and methionine [7-10]. $\mathrm{Pt}(\mathrm{DACH}) \mathrm{Cl}_{2}$, $\mathrm{Pt}(\mathrm{DACH}) \mathrm{Cl}(\mathrm{OH})$, and dihydrated OXP complex (DOC) are thought to be active biotransformation products of OXP. However, those products do not make a significant contribution to the cytotoxicity of OXP even though they are known to be more cytotoxic than OXP in cellular assays [11-13]. Conventionally, total free platinum of OXP in plasma ultrafiltrates (PUF) is measured by flame atomic absorption spectroscopy (FAAS) or the more sensitive inductively coupled plasma mass spectrometry (ICP-MS) [14,15]. However, the active fraction decreases with time as OXP is biotransformed to inactive metabolites. Since those inactive biotransformed products of OXP are also included in PUF, the total free platinum concentration is often overestimated in the pharmacokinetics (PK) study of the active components [16]. Furthermore, the parent OXP is the major active platinum complex at least during the first few hours following OXP infusion in humans. Therefore, parent OXP quantification is more important for the PK evaluation, and a sensitive and reliable bioanalytical method for the quantification of parent OXP is critically needed for in vivo studies [17]. Falta et al. [18] have developed a rapid and robust quantification method for oxaliplatin and other cancerostatic platinum compounds (CPC) by ICP- sector field MS (ICP-SFMS) and hydrophilic interaction liquid chromatography (HILIC) combined with ICP quadrupole-base instrument (ICP-QMS) detection. ICP-SFMS was used to quantify the total platinum concentrations from volunteer male subjects' whole blood compartments, while the HILIC-ICP-QMS method can be used to quantify intact CPC concentrations using CPC spiked plasma samples concentration. However, their method was neither validated nor applied to pharmacokinetics analysis. In addition, since only one third of the oxaliplatin is present as parent compound in unbounded plasma fraction, a more accurate species-specified method is needed.

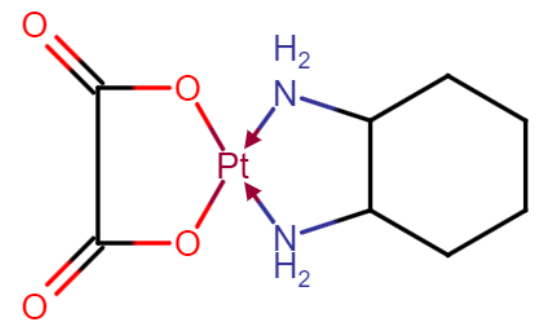

Figure 1. Chemical structure of oxaliplatin (OXP).

Oral mucosal drug delivery has unique benefits compared to other routes of administration. It avoids the first-pass effect from liver and gastrointestinal (GI) tract. It also has the potential to reduce systemic side effect with less systemic circulation exposure, to improve patient compliance, to provide fast on-site action and localized delivery, as well as to offer flexible dosing [19]. There are three categories of drug delivery in the oral mucosal cavity: sublingual delivery, buccal delivery, and local delivery [20]. Matos et al. [21] have reported the ex vivo application of mucoadhesive topical treatment in porcine tongue using polymeric OXP nanoparticles and substantiated the feasibility of topical therapy by showing an increase of drug penetration ex vivo. However, no previous studies have investigated the topical administration in oral mucosa in vivo to the best of our knowledge.

To date, there are only two studies that reported parent OXP quantification by liquid chromatography with tandem mass spectrometry (LC-MS/MS) in plasma, with a lower limit of quantification (LLOQ) of 20 and $25 \mathrm{ng} / \mathrm{mL}$ [22,23]. In this study, a novel bioanalytical method with a much higher sensitivity $(10 \mathrm{ng} / \mathrm{mL}$ LLOQ and $5 \mathrm{ng} / \mathrm{mL}$ lower limit of detection (LOD)) was developed and validated for the quantification of parent OXP in rat plasma and tongue tissue samples after supralingual administration of a novel OXP patch in rats. 


\section{Results and Discussion}

\subsection{Method Development}

2.1.1. Mass Spectrometry

${ }^{194} \mathrm{Pt},{ }^{195} \mathrm{Pt},{ }^{196} \mathrm{Pt}$ and ${ }^{198} \mathrm{Pt}$ are four major natural isotopes of platinum. Their content ratios in nature are $32.9 \%, 33.9 \%, 25.3 \%$ and $7.2 \%$, respectively. Thus, positive ion full scan mass spectra (Q1) of OXP molecular ion $[\mathrm{M}+\mathrm{H}]^{+}$exhibited $m / z$ values of 397, 398, 399 and 401 [22]. The strongest $m / z 398$ was chosen as the precursor ion. The electrospray ionization (ESI) mode resulted in lower noise background and better signal intensities for both OXP and IS. Multiple reaction monitoring (MRM) mode was used to identify the molecules by monitoring the transition $m / z \quad 398.1 \rightarrow 306.0$ for OXP and $m / z \quad 189.0 \rightarrow 131.0$ for the IS. For the OXP, $m / z 306$ is generated by the loss of two HCOOH molecules from protonated molecular ions $\left([\mathrm{M}+\mathrm{H}]^{+}-2 \mathrm{HCOOH}\right)$. For the IS, $m / z 131$, a stable conjugated $\pi$ bond system $\left[\mathrm{CH}=\mathrm{CH}-\mathrm{N}=\mathrm{N}-\mathrm{C}_{6} \mathrm{H}_{5}\right]^{+}$, is formed after the loss of a molecule of $\mathrm{CH}_{3} \mathrm{COCH}_{3}$. Those daughter ions were stable to be used in quantification. Since stable isotope-labeled OXP was not available on the market, antipyrine was chosen as an IS based on its appropriate retention time and no interference in this method. The product ion mass spectra for OXP is shown in Figure 2. Instrument MS source- and compound-dependent parameters were optimized by tuning to improve OXP sensitivity. The method was validated using these optimized conditions as described in the method.

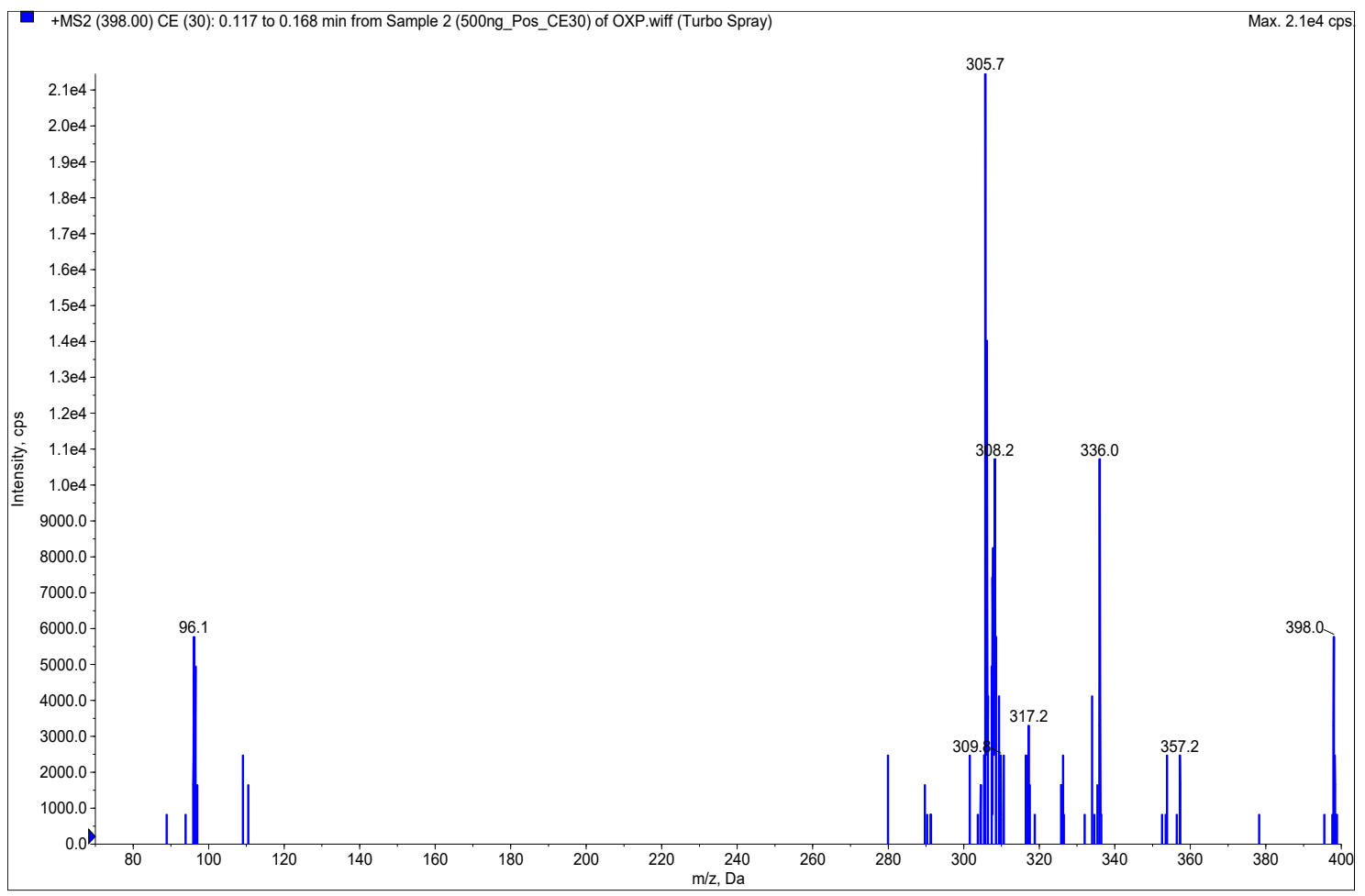

Figure 2. Product ion mass spectra of OXP $(\mathrm{m} / \mathrm{z}: 398.06 \rightarrow 306.00)$.

\subsubsection{Chromatography Separation}

OXP and internal standard (IS) were separated on a Phenomenex Lux $5 \mathrm{u}$ Cellulose-1 column $(250 \times 4.6 \mathrm{~mm}, 5 \mu \mathrm{m})$. Several other short stationary phase columns were tested, including the Kinetex ${ }^{\circledR}$ F5 column $(50 \times 2.1 \mathrm{~mm}, 1.7 \mu \mathrm{m})$, Acquity HSS-T3 $(50 \times 2.1 \mathrm{~mm}$, $1.8 \mu \mathrm{m})$ and ACE Excel 2 Super $C_{18}$ column $(50 \times 2.1 \mathrm{~mm}, 2 \mu \mathrm{m})$, and Phenomenex Lux $5 \mathrm{u}$ Cellulose- 1 column $(100 \times 4.6 \mathrm{~mm}, 5 \mu \mathrm{m})$. However, all of them showed serious signal inhibition for plasma samples, suggesting that the OXP signal might be interfered with by endogenous substances. With a longer Phenomenex Lux 5u Cellulose- 1 column, the simple isocratic elution could separate OXP and IS more efficiently than the other columns, where 
retention times of OXP and IS were $3.48 \mathrm{~min}$ and $4.54 \mathrm{~min}$, respectively. Notably, $1.25 \mathrm{mM}$ of ammonia formate was needed for the mobile phase to obtain consistent signal, indicating that the $\mathrm{pH}$ of mobile phase could affect the quality of the LC-MS/MS analyzing method. Different $\mathrm{pH}$ of mobile phase has been investigated, it being observed that adding $0.05 \%$ and $0.1 \%$ of formic acid to mobile phase under same condition could lead to double peak at high concentration, and the neutral mobile phase without adding acidic or alkaline solution could lead to unstable sensitivity of OXP. The final UHPLC method was optimized by selecting and testing different types of column, mobile phase compositions and flow rates to obtain better peak shapes, less carryover and higher sensitivity. As shown in Figures 3 and 4, IS had no interference with OXP. There was also no carryover detected in either blank plasma or tongue homogenate samples after six injections of ULOQ by a simple needle wash method. By comparing our method to the previous reported HILIC-ICP-QMS method [18], we gain advantages by using a simple isocratic elution method instead of a gradient elution method with shorter retention time (3.50 min verse $6.9 \mathrm{~min}$ ).

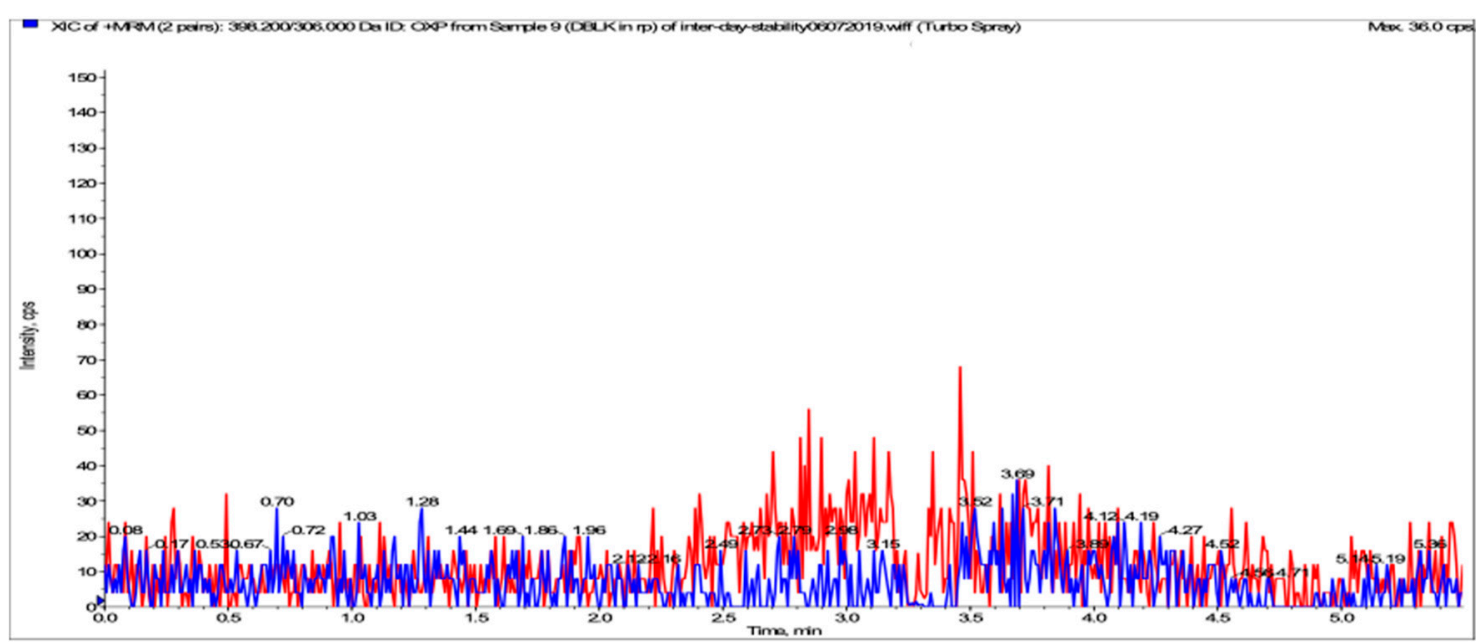

(a)

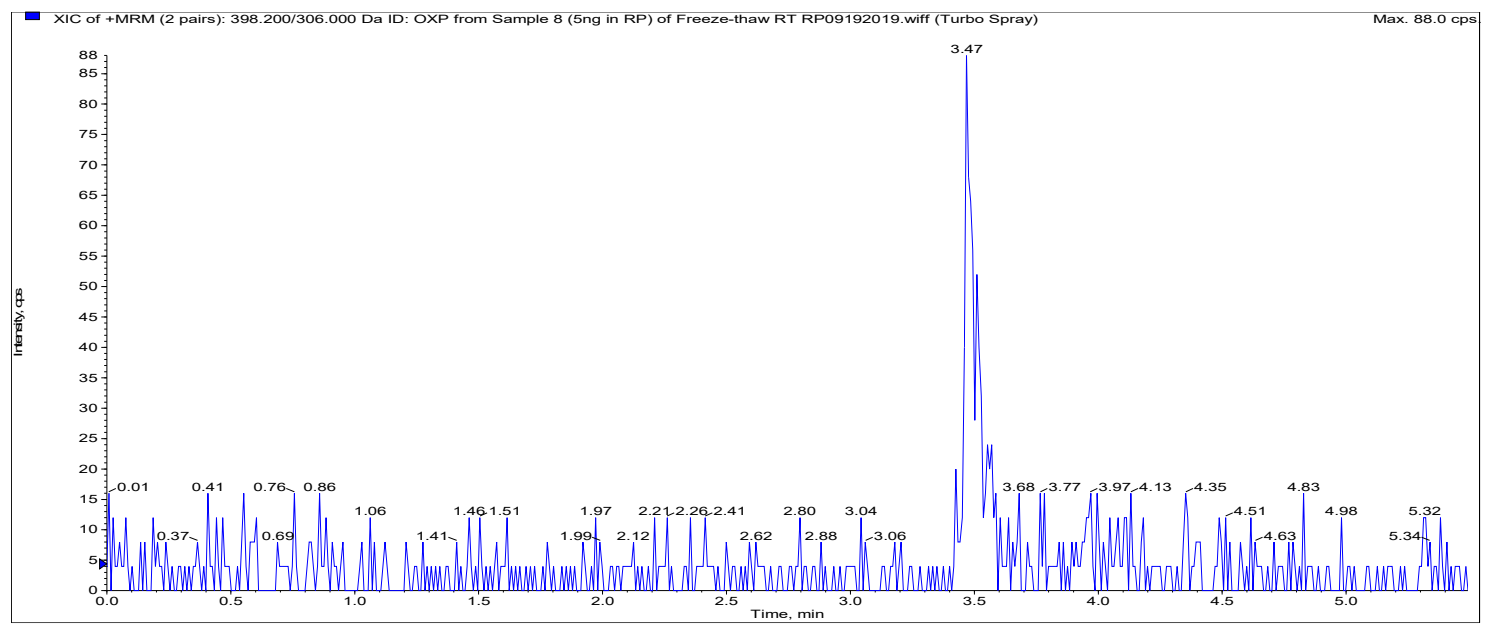

(b)

Figure 3. Cont. 


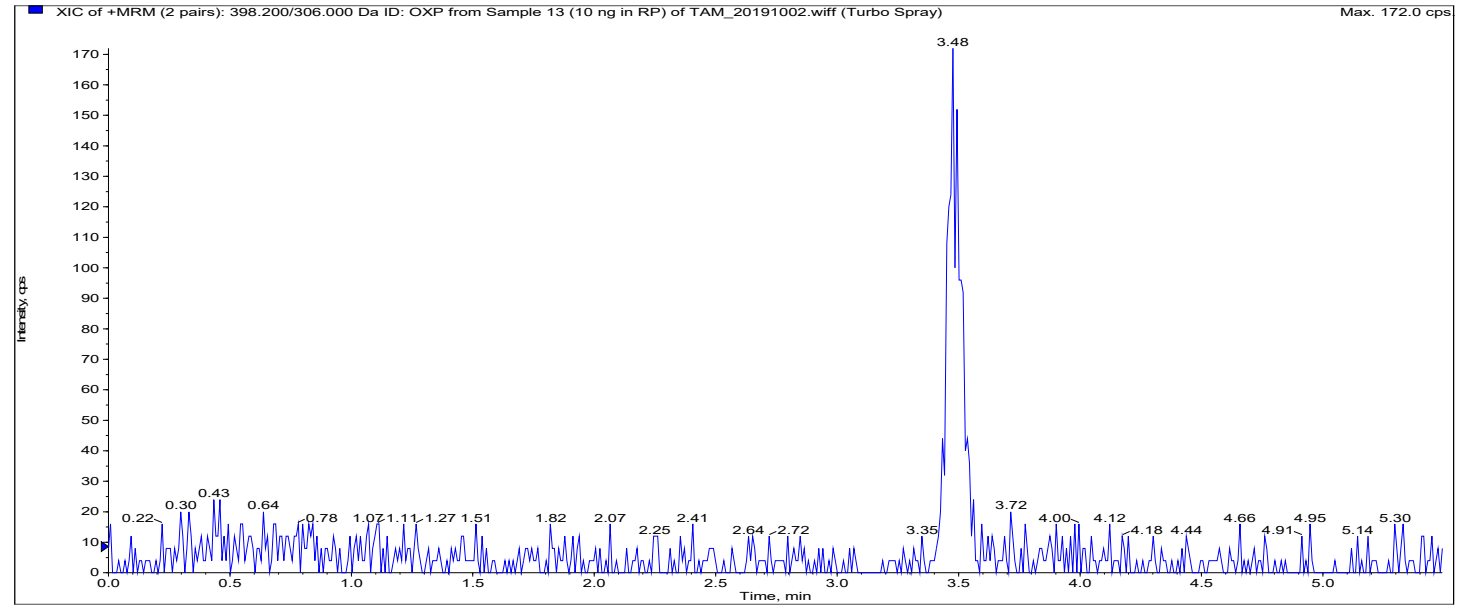

(c)

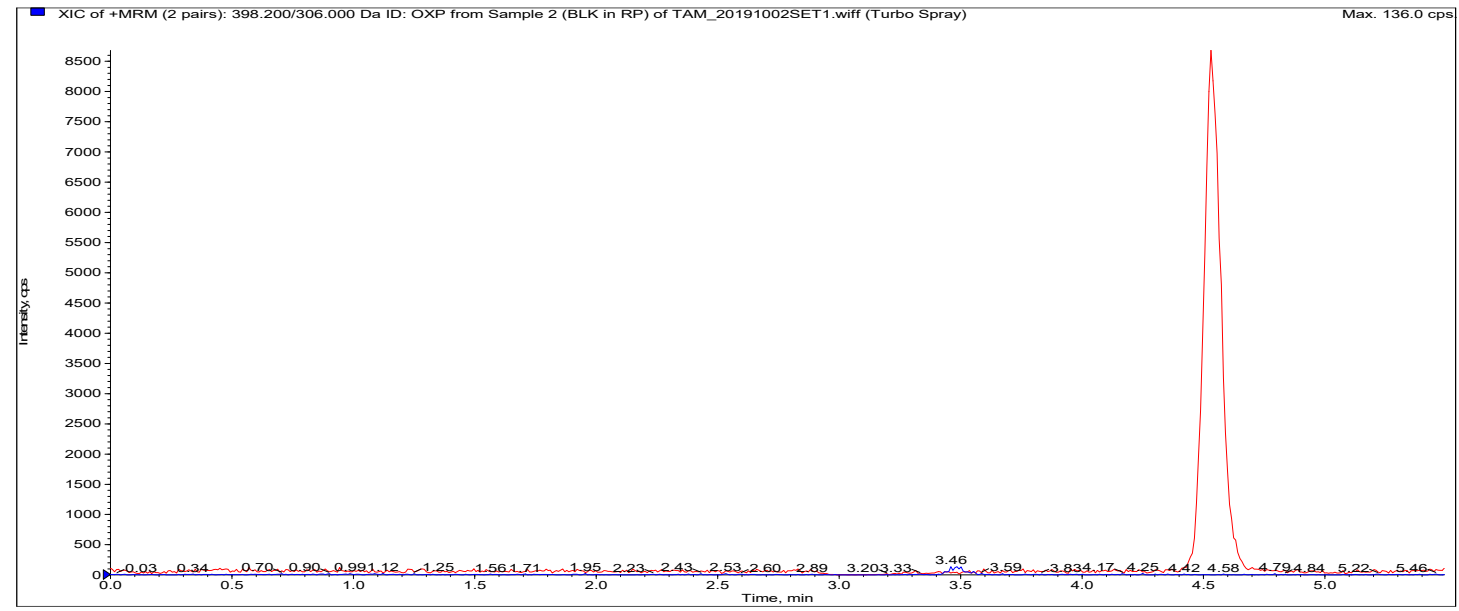

(d)

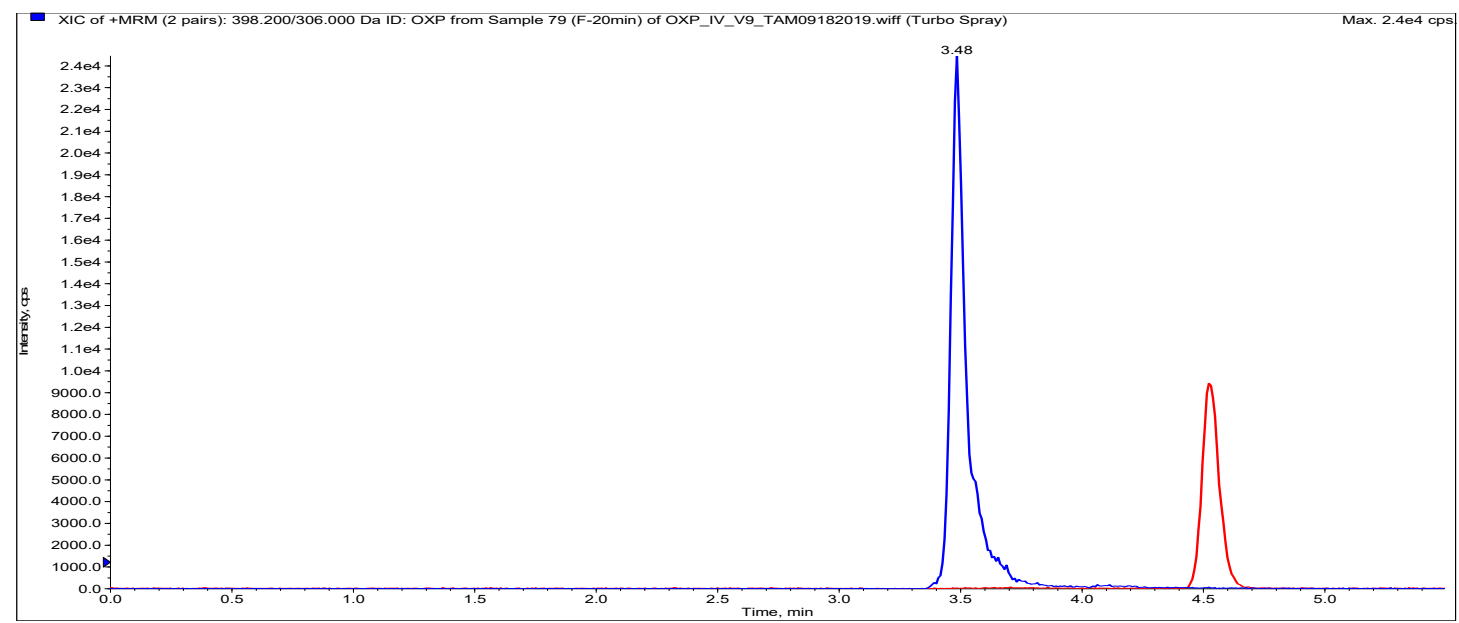

(e)

Figure 3. Representative chromatograms of OXP and internal standard (IS) in blank and spiked rat plasma: (a) blank plasma, (b) OXP spiked in plasma at the lower limit of detection $(5 \mathrm{ng} / \mathrm{mL})$, (c) OXP spiked in plasma at the lower limit of quantification $(10 \mathrm{ng} / \mathrm{mL})$, (d) blank plasma spiked with IS, (e) rat plasma sample at $20 \mathrm{~min}$ after $25 \mathrm{mg} / \mathrm{kg}$ body weight (BW) intravenous (IV) administration. OXP transition depicted in blue and IS transition depicted in red. 


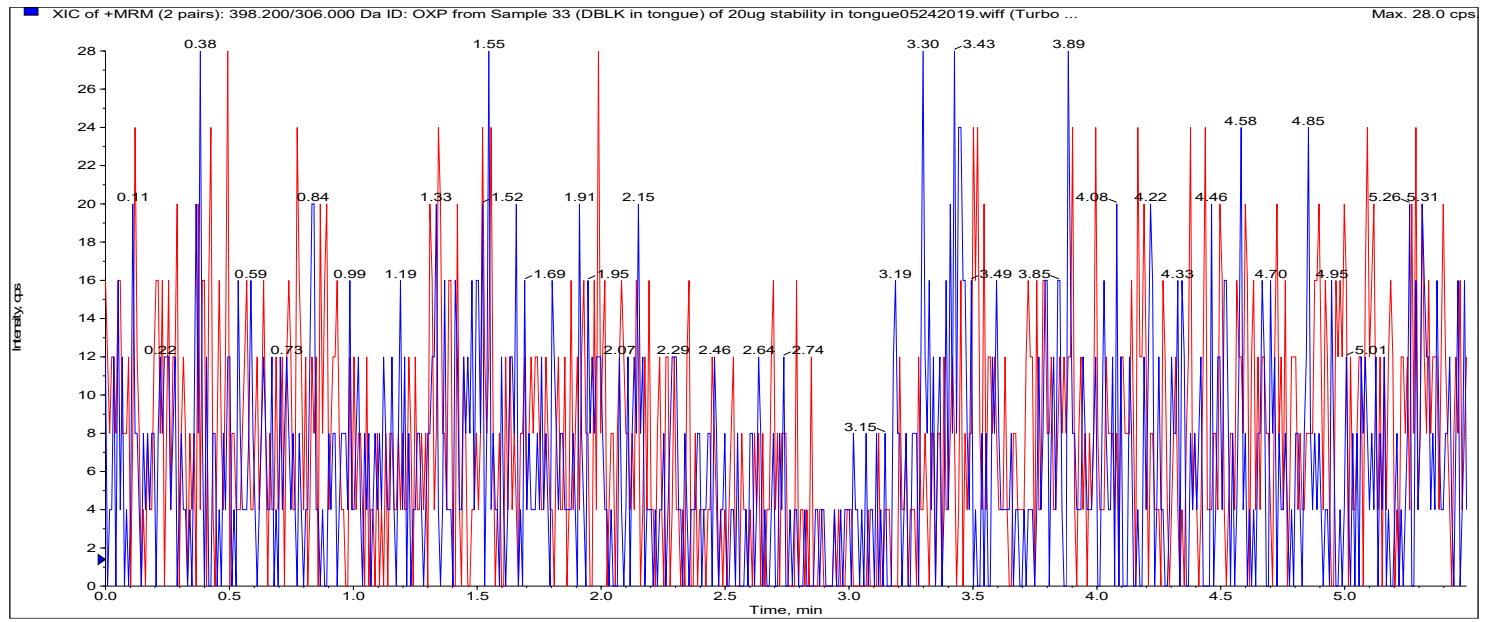

(a)

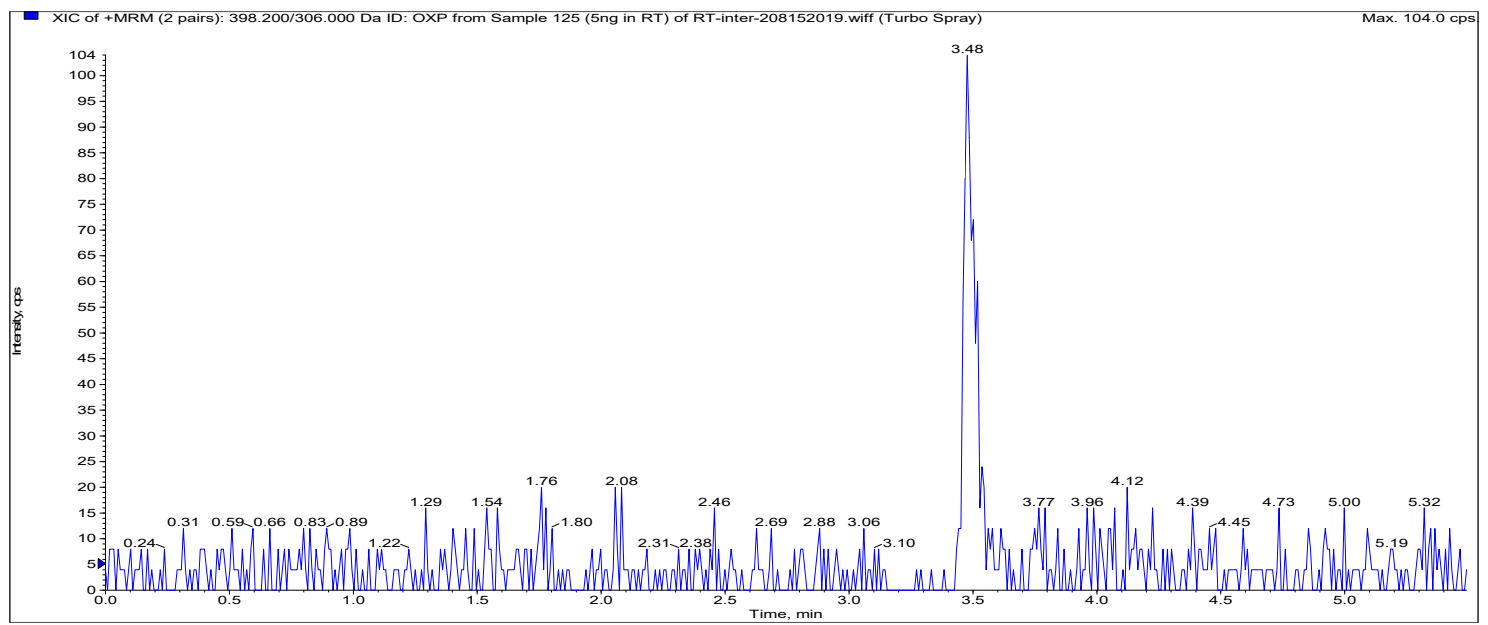

(b)

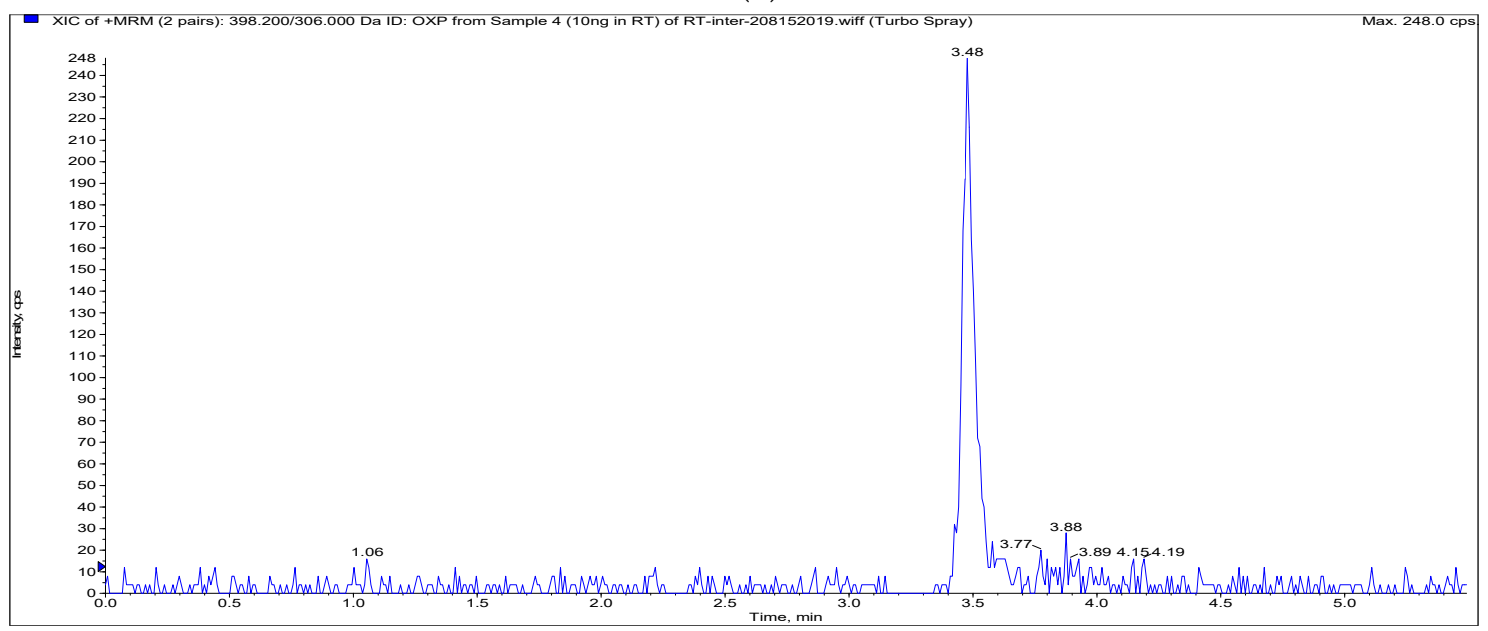

(c)

Figure 4. Cont. 


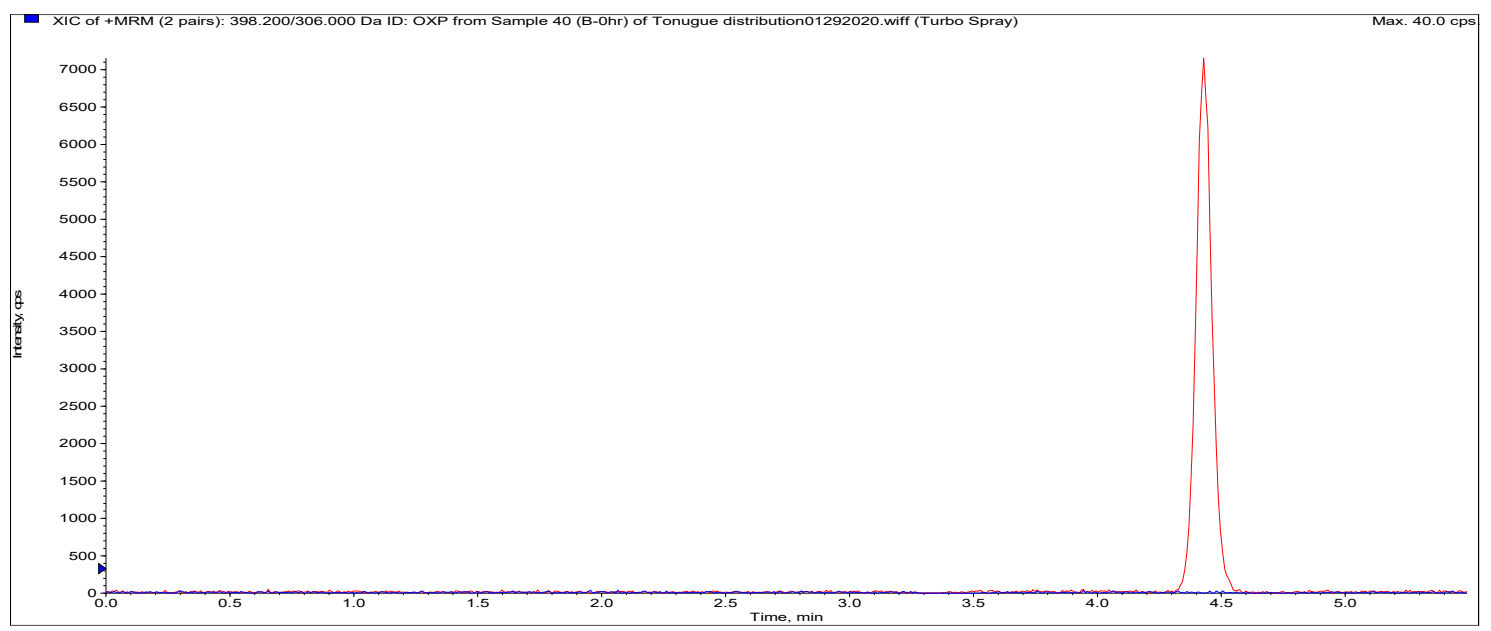

(d)

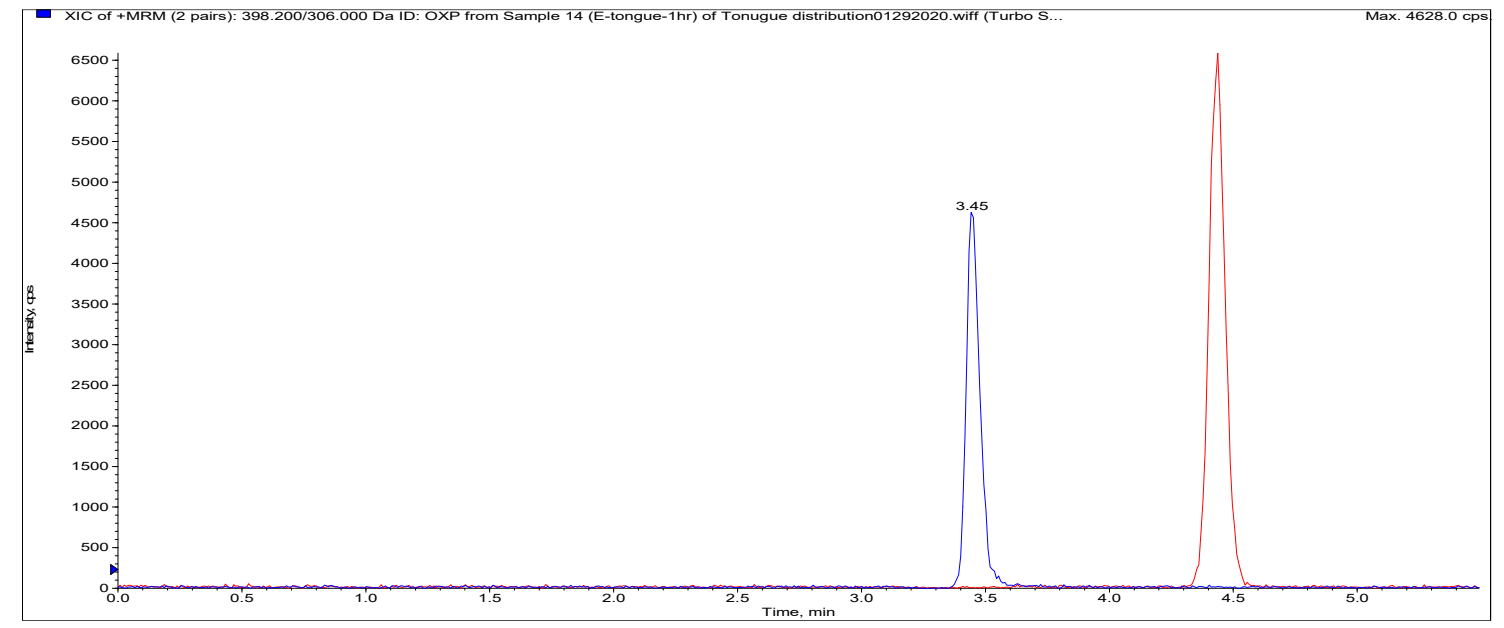

(e)

Figure 4. Representative chromatograms of OXP and IS in blank and spiked tongue homogenates: (a) blank tongue homogenates, (b) OXP spiked in tongue homogenates at the lower limit of detection $(5 \mathrm{ng} / \mathrm{mL})$, (c) OXP spiked in tongue homogenates at the lower limit of quantification $(10 \mathrm{ng} / \mathrm{mL})$, (d) blank tongue homogenates spiked with internal standard, (e) rat tongue sample at $1 \mathrm{~h}$ following patch application. OXP transition depicted in blue and IS transition depicted in red.

\subsection{Method Validation}

\subsubsection{Selectivity and Specificity}

As shown in Figures 3 and 4, there was no interference or significant ion suppression detected from endogenous matrix components, and there was no carryover for either IS ( $\leq 5 \%$ of average response) or OXP ( $\leq 20 \%$ of LLOQ), which meets the FDA's bioanalytical guidelines [24].

\subsubsection{Sensitivity and Linearity}

The standard curve showed good linearity from $10 \mathrm{ng} / \mathrm{mL}$ to $5000 \mathrm{ng} / \mathrm{mL}$ for plasma and $10 \mathrm{ng} / \mathrm{mL}$ to $2500 \mathrm{ng} / \mathrm{mL}$ for tongue homogenates. Linear correlation coefficients $\left(\mathrm{r}^{2}\right)$ were at least 0.99 (e.g., $y=0.00088 x+0.00125$ with $r^{2}=1.0000$ for rat plasma; $\mathrm{y}=0.00146 \mathrm{x}+0.00634$ with $\mathrm{r}^{2}=0.9994$ for tongue homogenates) for all calibration curves. The accuracy was within $85-115 \%$ for plasma and tongue homogenate calibration standards at all concentration levels. LOD of the assay was $5 \mathrm{ng} / \mathrm{mL}$ and LLOQ was $10 \mathrm{ng} / \mathrm{mL}$ for both plasma and tongue homogenates, where LOD had at least 3:1 and LLOQ had at least 5:1 signal-to-noise ratio (Figures 3 and 4). Lower LOD and LLOQ levels have been achieved 
with a simpler sample preparation than previous studies by LC-MS/MS (LLOQ: 20 and $25 \mathrm{ng} / \mathrm{mL}$ ) and by HILIC-ICP-QMS (LLOQ: $40 \mathrm{ng} / \mathrm{mL}$ ) [18,22,23].

\subsubsection{Accuracy and Precision}

The inter-day and intra-day accuracy and precision were determined at the LLOQ, LQC (low quality control), MQC (medium quality control), HQC (high quality control) in rat plasma and tongue homogenates with five replicates (Table 1). The intra-day and inter-day accuracy (relative error $=\mathrm{RE} \%$ ) ranged from $-6.70 \%$ to $4.21 \%$ and $-4.68 \%$ to $4.48 \%$ in the plasma and tongue homogenates, respectively. The precision (coefficient of variation $=\mathrm{CV} \%$ ) ranged from $2.96 \%$ to $8.67 \%$ and $2.37 \%$ to $7.88 \%$ in the plasma and tongue homogenates, respectively. The precision and accuracy were within the acceptance range according to FDA bioanalysis guidance. These results suggest that OXP in the plasma and tongue homogenates can be measured accurately and reproducibly by the present method.

Table 1. Intra-day and inter-day accuracy and precision of OXP in rat plasma and tongue homogenates.

\begin{tabular}{|c|c|c|c|c|c|c|c|}
\hline & \multirow[b]{2}{*}{$\begin{array}{c}\text { QCs } \\
\text { (ng/mL) }\end{array}$} & \multicolumn{3}{|c|}{ Intra-Day $(n=5)$} & \multicolumn{3}{|c|}{ Inter-Day $(n=15)$} \\
\hline & & $\begin{array}{c}\text { Observed } \\
\text { Concentration } \\
(\text { Mean } \pm \text { SD) }\end{array}$ & $\mathrm{RE} \%$ & $\mathrm{CV} \%$ & $\begin{array}{c}\text { Observed } \\
\text { Concentration } \\
(\text { Mean } \pm \text { SD) }\end{array}$ & $\mathrm{RE} \%$ & $\mathrm{CV} \%$ \\
\hline \multirow[t]{4}{*}{ Plasma } & 10 & $9.94 \pm 0.85$ & -0.63 & 8.54 & $9.84 \pm 0.42$ & -1.68 & 4.32 \\
\hline & 25 & $24.86 \pm 2.15$ & -0.58 & 8.67 & $26.10 \pm 1.09$ & 4.21 & 4.19 \\
\hline & 2000 & $1874.44 \pm 87.40$ & -6.70 & 4.66 & $1903.33 \pm 70.05$ & -5.08 & 3.68 \\
\hline & 4000 & $3985.00 \pm 249.55$ & -0.38 & 6.26 & $4065.00 \pm 120.12$ & 1.60 & 2.96 \\
\hline \multirow[t]{4}{*}{ Tongue } & 10 & $10.43 \pm 0.44$ & 4.15 & 4.19 & $10.45 \pm 0.54$ & 4.48 & 5.17 \\
\hline & 25 & $23.88 \pm 0.95$ & -4.68 & 3.97 & $24.95 \pm 1.97$ & -0.20 & 7.88 \\
\hline & 800 & $783.33 \pm 52.95$ & -2.13 & 6.76 & $798.22 \pm 49.90$ & -0.22 & 6.25 \\
\hline & 2000 & $2000 \pm 47.33$ & 0.00 & 2.37 & $2059.44 \pm 109.52$ & 2.97 & 5.32 \\
\hline
\end{tabular}

$\mathrm{SD}$, standard deviation; $\mathrm{CV}$, coefficient of variation; $\mathrm{RE}$, relative error, $\mathrm{QCs}=$ quality controls.

\subsubsection{Dilution Integrity}

A dilution integrity study was performed to check if sample dilution changed signals compared to the predicting concentration. All of them were within $\pm 15 \%$ of nominal concentration, indicating that the dilution was reliable for quantification of samples with higher OXP concentration than ULOQ.

\subsubsection{Matrix Effect and Extraction Recovery}

The extraction recovery and matrix effect from different biological matrices are shown in Table 2 . The matrix effects in the plasma ranged from $37.17 \%$ to $47.02 \%$ and the recovery was around $50 \%$, which implied that plasma contents significantly suppressed the signal and decreased the extraction efficiency for OXP, and it might explain why it was difficult to increase sensitivity as reported by previous studies. Matrix effects might be reduced by diluting samples with more acetonitrile. However, the sensitivity of OXP should be considered. Matrix effects in tongue homogenates were all less than $15 \%$ and the recovery ranged from $80.12 \%$ to $86.36 \%$, suggesting a negligible matrix effect and good extraction efficiency in tongue homogenates. 
Table 2. Recovery and matrix effect of OXP in rat plasma and tongue homogenates quality control (QC) samples.

\begin{tabular}{cccc}
\hline \multirow{2}{*}{ Biological Samples } & $\begin{array}{c}\text { Nominal Concentration } \\
(\mathbf{n g} / \mathbf{m L})\end{array}$ & Matrix Effect (\%) & Recovery (\%) \\
\cline { 3 - 4 } & 10 & $(\boldsymbol{n = 6 )}$ & $(\boldsymbol{n}=\mathbf{6})$ \\
\hline Plasma & 25 & $37.02 \pm 2.32$ & $51.89 \pm 1.50$ \\
\hline Tongue & 2000 & $46.61 \pm 2.06$ & $53.60 \pm 2.24$ \\
\hline & 4000 & $43.24 \pm 3.14$ & $52.80 \pm 6.85$ \\
\hline & 10 & $12.43 \pm 6.55$ & $86.36 \pm 7.00$ \\
\hline & 25 & $1.26 \pm 9.25$ & $80.12 \pm 7.38$ \\
\hline & 800 & $0.18 \pm 6.36$ & $82.30 \pm 5.99$ \\
\hline & 2000 & $2.71 \pm 6.71$ & $84.32 \pm 2.81$ \\
\hline
\end{tabular}

\subsubsection{Stability}

OXP stability in rat plasma and tongue homogenates was tested for short-term stability, freeze-thaw stability, auto-sampler stability, and long-term stability at four QC levels with triplicates (Tables 3 and 4). Bench-top stability, performed at $4{ }^{\circ} \mathrm{C}$ for $6 \mathrm{~h}$, was with acceptable $\mathrm{CV} \%$ and $\mathrm{RE} \%$ (within $15 \%$ ), indicating that the samples were stable under the laboratory handling condition. QCs in auto-sampler were also stable for $6 \mathrm{~h}$, demonstrating the stability of extracts throughout the process. There were $36.38 \%$ loss of OXP in rat plasma and $45.34 \%$ loss in rat tongue samples after three freeze-thaw cycles. In contrast, less than $15 \%$ of OXP loss with acceptable CV\% and RE\% were achieved after one and two cycles of freeze-thaw in both rat plasma and tongue homogenates. These results indicate that, after rat plasma and tongue samples are collected from PK and tissue distribution study, samples should be divided into several tubes before $-80^{\circ} \mathrm{C}$ storage to avoid frequent freeze-thaws, and should be analyzed within 7 days, as a significant loss of OXP is expected after 30 days of storage even at $-80{ }^{\circ} \mathrm{C}$. Stock solutions for OXP and IS are stable at $4{ }^{\circ} \mathrm{C}$ for up to 6 months.

Table 3. Stability data for OXP in rat plasma.

\begin{tabular}{|c|c|c|c|c|}
\hline & $\begin{array}{c}\text { Nominal } \\
\text { Concentration } \\
(\mathrm{ng} / \mathrm{mL})\end{array}$ & $\begin{array}{c}\text { Calculated } \\
\text { Concentration } \\
(\mathrm{ng} / \mathrm{mL})\end{array}$ & Precision & Accuracy \\
\hline & & Mean \pm SD & CV\% & $\mathrm{RE} \%$ \\
\hline \multirow{4}{*}{$\begin{array}{c}\text { auto-sampler }(6 \mathrm{~h}) \\
15^{\circ} \mathrm{C}\end{array}$} & 10 & $9.58 \pm 0.48$ & $4.98 \%$ & $-4.25 \%$ \\
\hline & 25 & $25.15 \pm 2.40$ & $9.56 \%$ & $0.60 \%$ \\
\hline & 2000 & $1937.50 \pm 90.69$ & $4.68 \%$ & $-3.13 \%$ \\
\hline & 4000 & $3487.50 \pm 81.80$ & $2.35 \%$ & $-12.81 \%$ \\
\hline \multirow{4}{*}{$\begin{array}{l}\text { short-term }(6 \mathrm{~h}) \\
4{ }^{\circ} \mathrm{C}\end{array}$} & 10 & $9.91 \pm 0.97$ & $9.77 \%$ & $-0.95 \%$ \\
\hline & 25 & $23.70 \pm 1.61$ & $6.81 \%$ & $-5.20 \%$ \\
\hline & 2000 & $2052.50 \pm 226.62$ & $11.04 \%$ & $2.63 \%$ \\
\hline & 4000 & $3577.50 \pm 102.10$ & $2.85 \%$ & $-10.56 \%$ \\
\hline \multirow{4}{*}{$\begin{array}{l}\text { 1-cycle-freeze thaw } \\
-80{ }^{\circ} \mathrm{C} \text { to RT }\end{array}$} & 10 & $9.46 \pm 0.69$ & $7.28 \%$ & $-5.43 \%$ \\
\hline & 25 & $23.45 \pm 1.25$ & $5.33 \%$ & $-6.20 \%$ \\
\hline & 2000 & $1950.00 \pm 133.42$ & $6.84 \%$ & $-2.50 \%$ \\
\hline & 4000 & $3985.00 \pm 270.62$ & $6.79 \%$ & $-0.38 \%$ \\
\hline
\end{tabular}


Table 3. Cont.

\begin{tabular}{|c|c|c|c|c|}
\hline & $\begin{array}{c}\text { Nominal } \\
\text { Concentration } \\
(\mathrm{ng} / \mathrm{mL})\end{array}$ & $\begin{array}{c}\text { Calculated } \\
\text { Concentration } \\
(\mathrm{ng} / \mathrm{mL})\end{array}$ & Precision & Accuracy \\
\hline & & Mean \pm SD & CV\% & $\mathrm{RE} \%$ \\
\hline \multirow{4}{*}{$\begin{array}{l}\text { 2-cycle-freeze thaw } \\
-80^{\circ} \mathrm{C} \text { to RT }\end{array}$} & 10 & $8.84 \pm 0.15$ & $1.70 \%$ & $-11.63 \%$ \\
\hline & 25 & $24.00 \pm 0.94$ & $3.91 \%$ & $-4.00 \%$ \\
\hline & 2000 & $1827.50 \pm 126.06$ & $6.90 \%$ & $-8.63 \%$ \\
\hline & 4000 & $3760.00 \pm 194.42$ & $5.17 \%$ & $-6.00 \%$ \\
\hline \multirow{4}{*}{$\begin{array}{l}\text { 3-cycle-freeze thaw } \\
-80{ }^{\circ} \mathrm{C} \text { to RT }\end{array}$} & 10 & $8.93 \pm 1.06$ & $11.90 \%$ & $-10.73 \%$ \\
\hline & 25 & $17.55 \pm 4.70$ & $26.81 \%$ & $-29.80 \%$ \\
\hline & 2000 & $1272.50 \pm 250.65$ & $16.16 \%$ & $-36.38 \%$ \\
\hline & 4000 & $2630.00 \pm 351.66$ & $13.37 \%$ & $-34.25 \%$ \\
\hline \multirow{4}{*}{$\begin{array}{l}\text { Long-term } \\
\text { (one month) } \\
\quad-80{ }^{\circ} \mathrm{C}\end{array}$} & 10 & $7.185 \pm 0.50$ & $6.90 \%$ & $-28.15 \%$ \\
\hline & 25 & $18.775 \pm 0.92$ & $4.89 \%$ & $-24.90 \%$ \\
\hline & 2000 & $1490 \pm 73.94$ & $4.96 \%$ & $-25.50 \%$ \\
\hline & 4000 & $2990 \pm 47.61$ & $1.59 \%$ & $-25.25 \%$ \\
\hline \multirow{4}{*}{$\begin{array}{l}\text { Long-term } \\
\text { (one week) } \\
-80{ }^{\circ} \mathrm{C}\end{array}$} & 10 & $9.74 \pm 0.21$ & $2.19 \%$ & $-2.60 \%$ \\
\hline & 25 & $26.9 \pm 0.48$ & $1.77 \%$ & $7.60 \%$ \\
\hline & 2000 & $2127.5 \pm 113.25$ & $5.32 \%$ & $6.38 \%$ \\
\hline & 4000 & $4387.5 \pm 195.34$ & $4.45 \%$ & $9.69 \%$ \\
\hline
\end{tabular}

$\mathrm{SD}$, standard deviation; $\mathrm{CV}$, coefficient of variation; $\mathrm{RE}$, relative error.

Table 4. Stability data for OXP in tongue homogenates.

\begin{tabular}{|c|c|c|c|c|}
\hline & $\begin{array}{c}\text { Nominal } \\
\text { Concentration } \\
(\mathrm{ng} / \mathrm{mL})\end{array}$ & $\begin{array}{c}\text { Calculated } \\
\text { Concentration } \\
(\mathrm{ng} / \mathrm{mL})\end{array}$ & Precision & Accuracy \\
\hline & & Mean \pm SD & CV\% & $\mathrm{RE} \%$ \\
\hline \multirow{4}{*}{$\begin{array}{l}\text { auto-sampler }(6 \mathrm{~h}) \\
15{ }^{\circ} \mathrm{C}\end{array}$} & 10 & $9.02 \pm 0.72$ & $8.02 \%$ & $-9.80 \%$ \\
\hline & 25 & $22.40 \pm 0.42$ & $1.89 \%$ & $-10.40 \%$ \\
\hline & 800 & $733.25 \pm 37.43$ & $5.10 \%$ & $-8.34 \%$ \\
\hline & 2000 & $1930.00 \pm 29.16$ & $2.03 \%$ & $-3.50 \%$ \\
\hline \multirow{4}{*}{$\begin{array}{c}\text { short-term }(6 \mathrm{~h}) \\
4{ }^{\circ} \mathrm{C}\end{array}$} & 10 & $10.23 \pm 1.43$ & $13.97 \%$ & $2.25 \%$ \\
\hline & 25 & $26.80 \pm 0.85$ & $3.17 \%$ & $7.20 \%$ \\
\hline & 800 & $858.00 \pm 62.06$ & $7.23 \%$ & $7.25 \%$ \\
\hline & 2000 & $2055.00 \pm 59.72$ & $2.91 \%$ & $2.75 \%$ \\
\hline \multirow{4}{*}{$\begin{array}{l}\text { 1-cycle-freeze thaw } \\
-80{ }^{\circ} \mathrm{C} \text { to RT }\end{array}$} & 10 & $10.875 \pm 0.26$ & $2.42 \%$ & $8.75 \%$ \\
\hline & 25 & $26.6 \pm 0.28$ & $1.06 \%$ & $6.40 \%$ \\
\hline & 800 & $812.5 \pm 79.33$ & $9.76 \%$ & $1.56 \%$ \\
\hline & 2000 & $1970 \pm 212.60$ & $10.79 \%$ & $-1.50 \%$ \\
\hline \multirow{4}{*}{$\begin{array}{l}\text { 2-cycle-freeze thaw } \\
-80{ }^{\circ} \mathrm{C} \text { to RT }\end{array}$} & 10 & $11.025 \pm 0.59$ & $5.31 \%$ & $10.25 \%$ \\
\hline & 25 & $25.05 \pm 0.78$ & $3.11 \%$ & $0.20 \%$ \\
\hline & 800 & $696.00 \pm 13.66$ & $1.96 \%$ & $-13.00 \%$ \\
\hline & 2000 & $1855.00 \pm 59.16$ & $3.19 \%$ & $-7.25 \%$ \\
\hline
\end{tabular}


Table 4. Cont.

\begin{tabular}{|c|c|c|c|c|}
\hline & $\begin{array}{c}\text { Nominal } \\
\text { Concentration } \\
(\mathrm{ng} / \mathrm{mL})\end{array}$ & $\begin{array}{l}\text { Calculated } \\
\text { Concentration } \\
(\mathrm{ng} / \mathrm{mL})\end{array}$ & Precision & Accuracy \\
\hline & & Mean \pm SD & CV\% & RE\% \\
\hline \multirow{4}{*}{$\begin{array}{l}\text { 3-cycle-freeze thaw } \\
-80{ }^{\circ} \mathrm{C} \text { to } \mathrm{RT}\end{array}$} & 10 & $6.57 \pm 0.29$ & $4.43 \%$ & $-34.35 \%$ \\
\hline & 25 & $15.70 \pm 0.99$ & $6.31 \%$ & $-37.20 \%$ \\
\hline & 800 & $437.25 \pm 67.07$ & $15.34 \%$ & $-45.34 \%$ \\
\hline & 2000 & $1097.50 \pm 20.62$ & $1.88 \%$ & $-45.13 \%$ \\
\hline \multirow{4}{*}{$\begin{array}{l}\text { Long-term } \\
\text { (one month) } \\
\quad-80{ }^{\circ} \mathrm{C}\end{array}$} & 10 & $9.96 \pm 0.75$ & $7.49 \%$ & $-0.45 \%$ \\
\hline & 25 & $20.60 \pm 1.27$ & $6.18 \%$ & $-17.60 \%$ \\
\hline & 800 & $507.75 \pm 16.01$ & $3.15 \%$ & $-36.53 \%$ \\
\hline & 2000 & $1232.50 \pm 90.32$ & $7.33 \%$ & $-38.38 \%$ \\
\hline \multirow{4}{*}{$\begin{array}{l}\text { Long-term } \\
\text { (one week) } \\
-80{ }^{\circ} \mathrm{C}\end{array}$} & 10 & $9.50 \pm 0.35$ & $3.71 \%$ & $-5.05 \%$ \\
\hline & 25 & $25.25 \pm 3.46$ & $13.72 \%$ & $1.00 \%$ \\
\hline & 800 & $731.25 \pm 12.84$ & $1.76 \%$ & $-8.59 \%$ \\
\hline & 2000 & $2045.00 \pm 186.28$ & $9.11 \%$ & $2.25 \%$ \\
\hline
\end{tabular}

$\mathrm{SD}$, standard deviation; $\mathrm{CV}$, coefficient of variation; $\mathrm{RE}$, relative error.

\subsection{Pharmacokinetics and Tongue Distribution Study}

No noticeable signs of discomfort were observed in rats after IV administration of OXP $(25 \mathrm{mg} / \mathrm{kg} \mathrm{BW})$ in $5 \%$ glucose solution. The mean plasma concentration versus time profile is shown in Figure 5. Plasma concentration of OXP at $2 \mathrm{~h}$ after administration was lower than the LLOQ. The main PK parameters for parent OXP were calculated using non-compartmental analysis $[25,26]$. Our results showed that the mean \pm SD plasma concentration was $22,600 \pm 2400 \mathrm{ng} / \mathrm{mL}$ at $2 \mathrm{~min}$ after IV administration. The mean plasma concentration-time curve during the period of observation $\left(\mathrm{AUC}_{0 \rightarrow 90 \mathrm{~min}}\right)$ was $200.4 \pm 35.6 \mathrm{~min} \cdot \mu \mathrm{g} / \mathrm{mL}$. The apparent volume of distribution $\left(\mathrm{V}_{\mathrm{d}}\right)$ was $867.0 \pm 75.3 \mathrm{~mL} / \mathrm{kg}$, the apparent clearance (CL) was $127.8 \pm 25.2 \mathrm{~mL} / \mathrm{min} / \mathrm{kg}$, and total body mean residence time (MRT) and terminal elimination half-life $\left(\mathrm{T}_{1 / 2}\right)$ were $6.9 \pm 0.7$ and $16.2 \pm 2.5 \mathrm{~min}$, respectively (Table 5). The findings are comparable to previously reported rat PK for parent OXP $[27,28]$, supporting the applicability of this method in a pre-clinical PK study of OXP.

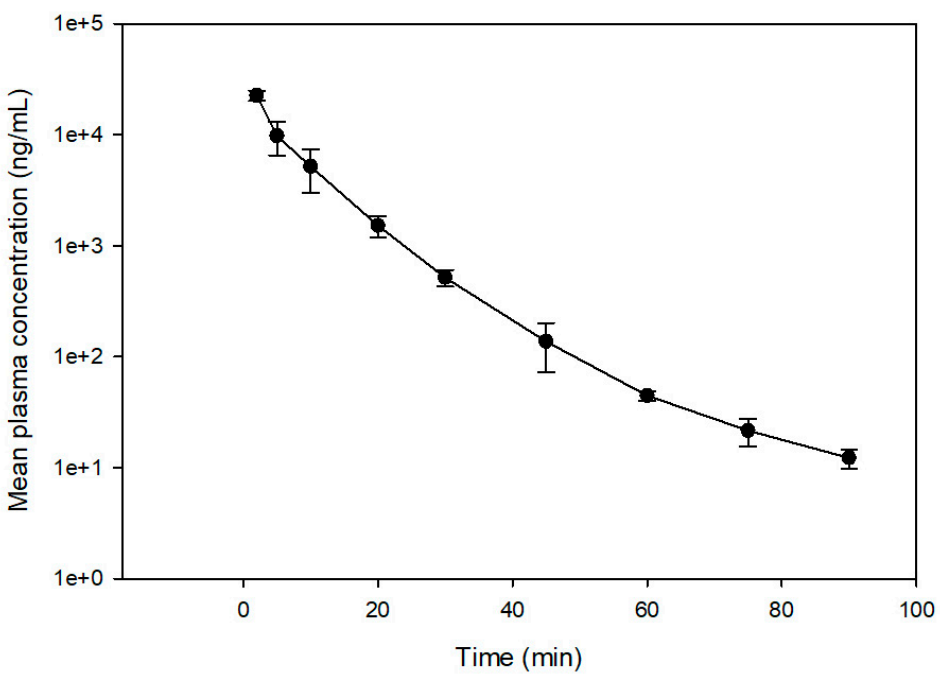

Figure 5. The profiles of the mean \pm SD plasma concentration versus time after $25 \mathrm{mg} / \mathrm{kg} \mathrm{BW}$ OXP intravenous injection to rats $(n=3)$. 
Table 5. Pharmacokinetics parameters of $25 \mathrm{mg} / \mathrm{kg}$ BW OXP after intravenous administration to rats $(n=3)$.

\begin{tabular}{ccccccccc}
\hline & & Rat A & Rat B & Rat C & Mean & SD & CV $/$ \\
\hline Parameter & Units & \multicolumn{5}{c}{ Estimate } \\
\hline $\mathrm{AUC}_{0 \rightarrow 90 \mathrm{~min}}$ & $\mathrm{~min} \cdot \mu \mathrm{g} / \mathrm{mL}$ & 159.40 & 217.62 & 224.09 & 200.37 & 35.63 \\
\hline $\mathrm{CL}$ & $\mathrm{mL} / \mathrm{min} / \mathrm{kg}$ & 156.84 & 114.88 & 111.56 & 127.76 & 25.24 & 19.8 \\
\hline $\mathrm{T}_{1 / 2}$ & $\mathrm{~min}$ & 16.85 & 13.50 & 18.27 & 16.21 & 2.45 & 15.1 \\
\hline $\mathrm{MRT}$ & $\mathrm{min}$ & 6.06 & 7.38 & 7.20 & 6.88 & 0.72 & 10.4 \\
\hline $\mathrm{V}_{\mathrm{d}}$ & $\mathrm{mL} / \mathrm{kg}$ & 949.91 & 848.24 & 802.80 & 866.98 & 75.32 & 8.7 \\
\hline
\end{tabular}

$\mathrm{SD}$, standard deviation; $\mathrm{CV}$, coefficient of variation; $\mathrm{AUC}_{0 \rightarrow 90 \mathrm{~min}}$, area under curve during $90 \mathrm{~min}$; $\mathrm{CL}$, clearance $\mathrm{T}_{1 / 2}$, half-life; $\mathrm{MRT}$, mean residence time; $\mathrm{V}_{\mathrm{d}}$, volume of distribution.

The OXP concentration in plasma after patch administration was lower than LOD. We determined the concentration of OXP in tongue homogenates at $1 \mathrm{~h}$ and $4 \mathrm{~h}$ following patch application, the mean \pm SD of tongue tissue concentrations were $2620 \pm 432 \mathrm{ng} / \mathrm{g}$ and $2834 \pm 664 \mathrm{ng} / \mathrm{g}$, respectively. The percentage values of OXP in patch residue and tongue tissues at $1 \mathrm{~h}$ and $4 \mathrm{~h}$ after supra-lingual application are presented in Figure 6. Around $28 \%$ and $22 \%$ of OXP remained in the patch formulation at $1 \mathrm{~h}$ and $4 \mathrm{~h}$, respectively. About $9 \%$ and $8 \%$ of OXP were accumulated inside tongue tissues at $1 \mathrm{~h}$ and $4 \mathrm{~h}$ after patch application, respectively. OXP tongue concentrations at $1 \mathrm{~h}$ and $4 \mathrm{~h}$ are similar, indicating that supralingual delivery can lead to long-term absorption and accumulation of OXP inside of the tongue tissue. The OXP patch may lead to a burst release within the first $1 \mathrm{~h}$ followed by a long-term sustained release [20]. In addition, our previous study on drug mycophenolic acid showed relatively lower plasma exposure in systemic circulation and higher accumulation in tongue tissue after supraglingual administration, suggesting that supralingual patch delivery may provide the benefits of longer drug accumulation in the tongue tissues and less systemic exposure [29].

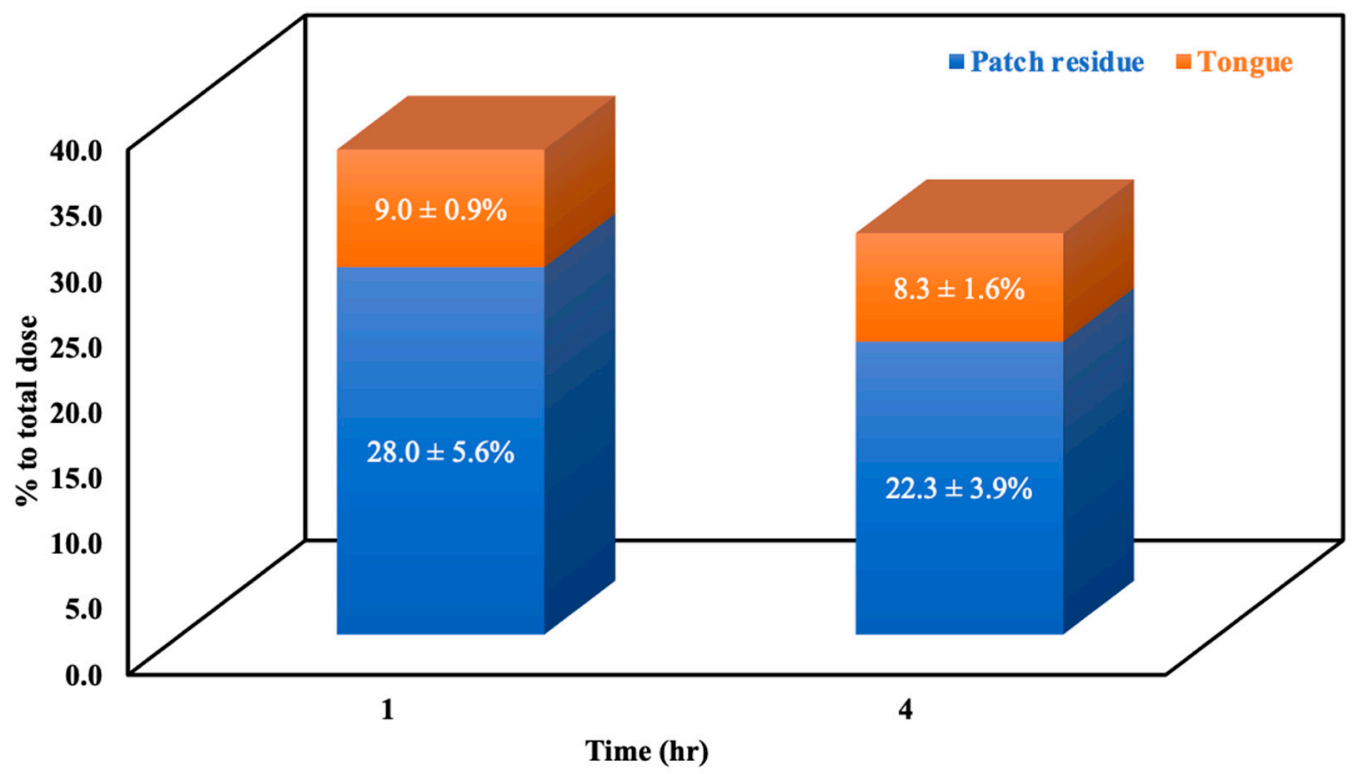

Figure 6. Patch residue and tongue tissue concentration percentage to total dosing of OXP by supralingual administration.

Several drug dosage formulations have been reported for intraoral application, including the implantable tablet, mucoadhesive patch, film, microsphere, ointment, cream, and hydrogel [30-35]. Most of these applications were instantaneously dissolved with a rapid onset, especially when administered at the non-keratinized sublingual and buccal 
surface [36,37]. The dorsal tongue has both non-keratinized and keratinized area, making it ideal for both local and systemic delivery [38,39]. Also, polyacrylic acid-974 (PAA) and carboxymethyl cellulose (CMC) are effective anionic polymers to maintain patch adhesion to oral mucosa [40]. Using a polymer-based patch formulation for topical drug delivery allows a sustained drug release [41]. In summary, the application of an OXP polymeric patch to dorsal tongue represented a novel study and warrants further investigation as a new therapeutic modality for intraoral lesions.

\section{Materials and Methods}

\subsection{Chemicals and Reagents}

OXP, antipyrine (as internal standard, IS), and ammonia formate were purchased from Sigma Aldrich (St. Louis, MO, USA). Acetonitrile and high-performance liquid chromatography (HPLC)-grade water were obtained from VWR Chemicals BDH (Chicago, IL, USA). Blank rat plasma used for the method's development and validation was purchased from Innovative Research (Novi, MI, USA).

\subsection{Animal Purchase and Procedures}

Adult male Sprague-Dawley rats were used in all animal studies and were purchased from Envigo RMS (Indianapolis, IN, USA) and tissues were from the non-treated rats. The animal experiments were approved (Protocol \#9080) by the Institutional Animal Care and Use Committee (IACUC) at Texas Southern University (TSU) and were conducted according to the National Institute of Health "Guide for the Care and Use of Laboratory Animals, 8th Edition".

\subsection{Instruments and Conditions}

The UHPLC-MS/MS system includes a Shimadzu Nexera X2 UHPLC system (Columbia, MD, USA) and a 4000 QTRAP ${ }^{\circledR}$ MS/MS system (AB Sciex, Redwood City, CA, USA). System control and data analysis were performed using the Analyst ${ }^{\circledR}$ software 1.6.2 (Sciex, Redwood City, CA, USA).

\subsubsection{Ultra High-Performance Liquid Chromatography (UHPLC) Conditions}

OXP separation was carried out on a Phenomenex Lux 5u Cellulose- 1 column $(250 \times 4.6 \mathrm{~mm}, 5 \mu \mathrm{m})$ with an isocratic elution of $50 \%(v / v)$ acetonitrile in water containing $1.25 \mathrm{mM}$ ammonia formate. The injection volume of each sample was $10 \mu \mathrm{L}$. The total run time was $5.5 \mathrm{~min}$. The flow rate was $0.8 \mathrm{~mL} / \mathrm{min}$.

\subsubsection{Tandem Mass Spectrometry (MS/MS) Conditions}

MRM data were collected by the MS using a Turbo $V^{\mathrm{TM}}$ source with ESI positive mode to detect the specific precursor-to-product ion transitions, $m / z 398.1 \rightarrow 306.0$ for OXP and $m / z 189.0 \rightarrow 131.0$ for IS antipyrine. The ion spray voltage was set at $5000 \mathrm{~V}$, and the source temperature was set at $700{ }^{\circ} \mathrm{C}$. The pressures of nebulizer gas and heater gas were $60 \mathrm{psi}$ and $55 \mathrm{psi}$, respectively. The optimized curtain gas pressure was $25 \mathrm{psi}$ and high collision gas "CAD" pressure was applied. Compound-dependent parameters for OXP and IS were optimized and set at 74 and $60 \mathrm{~V}$ for declustering potential (DP), 39 and $28 \mathrm{~V}$ for collision energy (CE), and 13 and $9 \mathrm{~V}$ for collision cell exit potential (CXP), respectively.

\subsection{Preparation of Stock Solutions, Calibration Standards and Quality Controls}

Stock solutions of OXP and IS were dissolved in water at a concentration of $1 \mathrm{mg} / \mathrm{mL}$ and stored at $4{ }^{\circ} \mathrm{C}$ until use. Standard samples were prepared by spiking OXP into blank rat plasma and rat tongue homogenates, respectively, at concentrations ranging $10-5000 \mathrm{ng} / \mathrm{mL}$ and $10-2500 \mathrm{ng} / \mathrm{mL}$ for rat plasma and tongue homogenates, respectively. Briefly, a series of working solutions of OXP were prepared by diluting stock solution in water to the appropriate concentrations (10 times as that of nominal concentration) for standards $(100,500,2500,5000,10,000,25,000,50,000 \mathrm{ng} / \mathrm{mL})$ in plasma and tissue 
homogenates. Working solutions were then spiked into blank rat plasma and blank tissue homogenates with 10 times dilution to make calibration standards. The final concentrations of standard samples were $10,50,250,500,1000,2500,5000 \mathrm{ng} / \mathrm{mL}$ in plasma. The final concentrations of calibration standards for tongue homogenates were 10, 50, 250, 500, 1000, $2500 \mathrm{ng} / \mathrm{mL}$ in tissue homogenates. Calibration standards were freshly prepared daily.

The working solutions for QC samples were independently prepared by diluting OXP standard solutions with water to give the concentrations of 100, 250, 20,000, and $40,000 \mathrm{ng} / \mathrm{mL}$, which were 10 times as that of nominal concentrations: 10 (LLOQ), 25 (LQC), 2000 (MQC) and $4000 \mathrm{ng} / \mathrm{mL}$ (HQC) for rat plasma. For tongue homogenates, the working solution concentrations of QC samples were 100, 250, 8000, and 20,000 ng/mL, and the corresponding nominal concentrations were 10 (LLOQ), 25 (LQC), 800 (MQC) and $2000 \mathrm{ng} / \mathrm{mL}$ (HQC).

\subsection{Extraction of OXP from Plasma and Tongue Samples}

Each weighted tongue tissue sample was homogenized in a clean scintillation vial with water $(1: 6, w / v)$ using the Biospec Tissue TearorTM (Bartlesville, OK, USA) to make tongue homogenates. Rat plasma or tongue homogenates were extracted by a protein precipitation method described in [4]. Briefly, $10 \mu \mathrm{L}$ of $100 \mathrm{ng} / \mathrm{mL}$ IS was added to $50 \mu \mathrm{L}$ of rat plasma or tongue homogenates samples. Next, the samples were extracted by $200 \mu \mathrm{L}$ of acetonitrile containing $0.01 \%(w / v)$ ammonium formate. After vortexing for $15 \mathrm{~s}$, the extracted samples were centrifuged at $14,000 \mathrm{rpm}$ for $20 \mathrm{~min}$ at $4{ }^{\circ} \mathrm{C}$. Finally, $10 \mu \mathrm{L}$ of supernatant was injected into the LC-MS/MS system. Sample preparation was performed on top of ice pads.

\subsection{Method Validation}

The assay on rat plasma and tongue sample homogenates were validated following the FDA and the EMA guidelines for bioanalytical method validation with specific aspects described below [24,42].

\subsubsection{Selectivity and Specificity}

The selectivity and specificity tests were conducted by comparing chromatograms of six different endogenous sources of blank rat plasma or tongue homogenates for interference with the analyte and IS. The peak response of the endogenous plasma and tongue homogenates for the analytes should be $\leq 20 \%$ of the peak area of the LLOQ standard, the IS should be $\leq 5 \%$ of the average peak area of the standard curve and QC samples.

\subsubsection{Sensitivity and Linearity}

The concentrations of OXP in unknown samples were calculated using linear calibration curves in plasma or tongue homogenates by plotting the peak area of the OXP-to-IS ratio against known standard concentrations of OXP. The slope, intercept, and coefficient of determination were estimated using least squares linear regression method with a weighting of " $1 / x$ ". The LOD was selected based on a signal-to-noise ratio of 3:1 and the LLOQ was estimated based on the signal-to-noise ratio of at least 5:1.

\subsubsection{Carryover}

Triplicate injections of blank samples were conducted following six consecutive injections of QC samples with the highest amounts (ULOQ $=5000 \mathrm{ng} / \mathrm{mL}$ for plasma, $2500 \mathrm{ng} / \mathrm{mL}$ for tongue homogenates). Carryover in the blank sample following the ULOQ should not be greater than $20 \%$ of the LLOQ for OXP and $5 \%$ for the IS.

\subsubsection{Accuracy and Precision}

Intra-day accuracy and precision were conducted at four QC levels of OXP concentrations in plasma and tongue homogenates on a single assay by five replicates. Inter-day accuracy and precision were determined by five replicates of four QC levels on three 
consecutive days. Accuracy was determined by the RE\%. Precision was determined by the $\mathrm{CV} \%$. Calculated results of inter-day and intra-day precision and accuracy should be $\leq 15 \%$, except for the LLOQ, where the absolute value of calculated concentrations should be $\leq 20 \%$.

\subsubsection{Dilution Integrity}

The dilution integrity of rat plasma performed to determine the accuracy of extended linearity beyond the ULOQ $(5000 \mathrm{ng} / \mathrm{mL})$. The dilution factors for dilutions of QC were 2, 5 and 10. Diluted quality control (DQC, $20 \mu \mathrm{g} / \mathrm{mL}$ ) samples were further diluted five and 10 times using plasma to measure the accuracy and precision of the dilution. Another DQC $(10 \mu \mathrm{g} / \mathrm{mL})$ plasma sample was further diluted two and five times to measure the accuracy and precision of the dilution.

\subsubsection{Extraction Recovery and Matrix Effect}

In this study, matrix effects were evaluated by comparing the peak area of the postextracted blank rat plasma or tongue homogenates to the peak area of neat solution at four QC levels (LLOQ, LQC, MQC, HQC) in five replicates. The calculated equation of the matrix effect is as follows:

$$
\text { Matrix effect } \%=\left[\left(\frac{\text { Response }_{\text {post-extraction spiked samples }}}{\text { Response }_{\text {neat solution samples }}}\right)-1\right] \times 100
$$

The extraction recovery was evaluated by comparing the peak area of the pre-extracted blank rat plasma or tongue QC sets to the peak area of the post-extracted QC sets. The calculated equation of extraction recovery is as follows:

$$
\text { Extraction recovery } \%=\left(\frac{\text { Response }_{\text {pre-extraction spiked samples }}}{\text { Response }_{\text {post-extraction spiked samples }}}\right) \times 100
$$

\subsubsection{Stability}

The stability of OXP in rat plasma or tongue homogenates was examined by shortterms, freeze-thaw, post-prepared auto-sampler, and long-term stability studies. All stability experiments were conducted at four QC levels (LLOQ, LQC, MQC, HQC) with five replicates. The short-term bench-top stability was tested by placing prepared QC samples at $4{ }^{\circ} \mathrm{C}$ for $6 \mathrm{~h}$. Auto-sampler stability was performed by placing QC samples inside of autosampler of LC-MS/MS for $6 \mathrm{~h}$, the auto-sampler temperature was set to $15^{\circ} \mathrm{C}$. Freeze-thaw stability was conducted by three cycles of freezing at $-80{ }^{\circ} \mathrm{C}$ and thawing at $4{ }^{\circ} \mathrm{C}$. Long-term stability was evaluated by placing the $\mathrm{QC}$ samples in $-80{ }^{\circ} \mathrm{C}$. OXP concentrations in all stability samples were compared to that of freshly made QC samples.

\subsection{Patch Formulation}

The polymer patches were fabricated by Cellink Bio X using a high-OXP-concentration solution containing $30 \mathrm{mg}$ of OXP, $0.05 \mathrm{~g}$ of PAA, $0.05 \mathrm{~g}$ of 3,4-dihydroxyphenylalanine (DOPA), $0.1 \mathrm{~g}$ of $\mathrm{CMC}$, and $5 \mathrm{~mL}$ of $\mathrm{H}_{2} \mathrm{O}$, on a supporting material. The concentration of $\mathrm{OXP}$ in each patch was $1.1 \mu \mathrm{g} / \mathrm{cm}^{2}$.

\subsection{Pharmacokinetics and Tongue Distribution Studies}

The validated method was applied to investigate the plasma profiles of OXP after IV administration of a $25 \mathrm{mg} / \mathrm{kg}$ BW OXP in $5 \%$ glucose solution, and tongue distribution of OXP after a supralingual administration of $150 \mu \mathrm{g}$ OXP patch $/ \mathrm{kg} \mathrm{BW}$ in rats. A group of three adult male SD rats was used for the PK studies. Serial blood samples (approximately $150 \mu \mathrm{L}$ for each) were collected in heparinized tubes at various time points up to $24 \mathrm{~h}$ after dosing. Plasma was separated immediately by centrifugation of the blood samples at $3000 \mathrm{rpm}$ for $20 \mathrm{~min}$ and kept at $-80^{\circ} \mathrm{C}$ until analysis. For the tongue tissue distribution 
and blood diffusion studies, six adult male SD rats were used for the study. A mucoadhesive patch formulation containing OXP was applied onto the dorsal tongue surface of a rat for $1 \mathrm{~h}(n=3)$ and $4 \mathrm{~h}(n=3)$, respectively, at a dose of $150 \mu \mathrm{g} / \mathrm{kg}$ BW under anesthesia. Serial blood samples (about $100 \mu \mathrm{L}$ each) were collected at 1, 2, 3 and $4 \mathrm{~h}$ from the start of the patch application to the end of patch application and stored in heparinized tubes. Blood samples were centrifuged at $3000 \mathrm{rpm}$ for $20 \mathrm{~min}$ to separate the plasma samples, then stored at $-80^{\circ} \mathrm{C}$ until analysis. Tongues were removed immediately after euthanasia, rinsed with deionized water three times, sliced into small pieces, and then homogenized in water $(1: 6 w / v)$. Blank tongues were prepared separately using drug-free rats. The PK parameters for each rat were estimated using the Phoenix WinNonlin software 8.2 (Certara, NJ, USA). Non-compartmental analysis was used to determine the PK parameters of OXP after IV administration [43].

\section{Conclusions}

In this study, we developed a rapid, sensitive, and reliable UHPLC-MS/MS method for measuring OXP in rat plasma and tongue homogenates. This method was properly validated over the concentration ranges of $10-2500 \mathrm{ng} / \mathrm{mL}$ and $10-5000 \mathrm{ng} / \mathrm{mL}$ for tongue homogenates and plasma, respectively. We have successfully applied this method to the PK study after IV administration of OXP and showed that the plasma concentration was quantifiable until $1.5 \mathrm{~h}$ after administration. Topical delivery of OXP to rat tongue tissue was also determined and showed similar tongue concentrations of OXP at $1 \mathrm{~h}$ and $4 \mathrm{~h}$ after patch application, indicating a burst penetration of OXP into tongue tissue before $1 \mathrm{~h}$ and a long-term sustained release until $4 \mathrm{~h}$ of the application.

Author Contributions: Conceptualization, D.L., H.X., X.G., R.Y.L.T.; methodology, X.G., Y.W., J.M., X.L.; formal analysis, X.G.; writing—original draft preparation, X.G., H.X., D.L., R.Y.L.T.; writingreview and editing, X.G., H.X., D.L., Y.W., R.Y.L.T., X.L.; supervision, H.X., D.L., R.Y.L.T.; project administration, H.X., D.L., R.Y.L.T.; funding acquisition, D.L., H.X., R.Y.L.T. All authors have read and agreed to the published version of the manuscript.

Funding: This study was funded by Cancer Prevention \& Research Institute of Texas (CPRIT) Early Translational Research Awards (RP170179), CPRIT Core Facilities Support Awards (RP180748), and the National Institute of Health's Research Centers in Minority Institutes Program (RCMI, U54MD007605).

Institutional Review Board Statement: All animal experiments were conducted according to protocols approved by the Institutional Animal Care and Use Committee of Texas Southern University.

Informed Consent Statement: Not applicable.

Data Availability Statement: The data has been presented in main text.

Acknowledgments: In this section, you can acknowledge any support given which is not covered by the author contribution or funding sections. This may include administrative and technical support, or donations in kind (e.g., materials used for experiments).

Conflicts of Interest: Authors declare no conflicts of interest.

\section{Abbreviations}

$\begin{array}{ll}\mathrm{AUC}_{0 \rightarrow 90 \mathrm{~min}} & \text { plasma concentration-time curve during the period of observation } \\ \mathrm{BW} & \text { body weight } \\ \mathrm{CAD} & \text { collision gas } \\ \mathrm{CE} & \text { collision energy } \\ \mathrm{CL} & \text { clearance } \\ \mathrm{CMC} & \text { carboxymethyl cellulose } \\ \mathrm{CPC} & \text { cancerostatic platinum compounds } \\ \mathrm{CV} \% & \text { coefficient of variation } \\ \mathrm{CXP} & \text { cell exit potential } \\ \mathrm{DACH} & \text { diaminocyclohexane }\end{array}$




$\begin{array}{ll}\text { DOC } & \text { dihydrated OXP complex } \\ \text { DOPA } & \text { 3,4-dihydroxyphenylalanine } \\ \text { DP } & \text { declustering potential } \\ \text { DQC } & \text { diluted quality control } \\ \text { EMA } & \text { European Medicines Agency } \\ \text { ESI } & \text { electrospray ionization } \\ \text { FAAS } & \text { flame atomic absorption spectroscopy } \\ \text { FDA } & \text { Food and Drug Administration } \\ \text { FOLFOX } & \text { chemotherapy regimen combined 5-fluorouracil, folic acid, and oxaliplatin } \\ \text { GI } & \text { gastrointestinal } \\ \text { HILIC } & \text { hydrophilic interaction liquid chromatography } \\ \text { HPLC } & \text { high-performance liquid chromatography } \\ \text { ICP-MS } & \text { Inductively Coupled Plasma Mass Spectrometry } \\ \text { ICP-QMS } & \text { ICP quadrupole-based instrument } \\ \text { ICP-SFMS } & \text { ICP-sector field MS } \\ \text { IS } & \text { internal standard } \\ \text { LC-MS } / M S & \text { liquid chromatography with tandem mass spectrometry } \\ \text { LLOQ } & \text { lower limit of quantification } \\ \text { LOD } & \text { lower limit of detection } \\ \text { MRM } & \text { multiple reaction monitoring } \\ \text { MRT } & \text { mean residence time } \\ \text { OSCC-25 } & \text { oral squamous cell carcinoma } \\ \text { OXP } & \text { oxaliplatin } \\ \text { PAA } & \text { polyacrylic acid-974 } \\ \text { PK } & \text { pharmacokinetics } \\ \text { PUF } & \text { plasma ultrafiltrates } \\ \text { QC } & \text { quality control } \\ \text { RE\% } & \text { relative error } \\ \text { SD } & \text { standard deviation } \\ \text { T1/2 } & \text { half-life } \\ \text { V } & \text { volume of distribution } \\ & \end{array}$

\section{References}

1. Oun, R.; Moussa, Y.E.; Wheate, N.J. The side effects of platinum-based chemotherapy drugs: A review for chemists. Dalton Trans. 2018, 47, 6645-6653. [CrossRef]

2. Dilruba, S.; Kalayda, G.V. Platinum-based drugs: Past, present and future. Cancer Chemother. Pharmacol. 2016, 77, 1103-1124. [CrossRef]

3. Lin, T.; Meng, L.; Tsai, R.Y. GTP depletion synergizes the anti-proliferative activity of chemotherapeutic agents in a cell typedependent manner. Biochem. Biophys. Res. Commun. 2011, 414, 403-408. [CrossRef] [PubMed]

4. Gao, X.; Tsai, R.Y.L.; Ma, J.; Bhupal, P.K.; Liu, X.; Liang, D.; Xie, H. Determination and validation of mycophenolic acid by a UPLC-MS/MS method: Applications to pharmacokinetics and tongue tissue distribution studies in rats. J. Chromatogr. B Analyt. Technol. Biomed. Life Sci. 2020, 1136, 121930. [CrossRef]

5. $\quad$ De Jong, L.A.W.; Elekonawo, F.M.K.; de Reuver, P.R.; Bremers, A.J.A.; de Wilt, J.H.W.; Jansman, F.G.A.; Heine, R.T.; van Erp, N.P. Hyperthermic intraperitoneal chemotherapy with oxaliplatin for peritoneal carcinomatosis: A clinical pharmacological perspective on a surgical procedure. Br. J. Clin. Pharmacol. 2019, 85, 47-58. [CrossRef] [PubMed]

6. Han, C.H.; Khwaounjoo, P.; Hill, A.G.; Miskelly, G.M.; McKeage, M.J. Predicting effects on oxaliplatin clearance: In vitro, kinetic and clinical studies of calcium- and magnesium-mediated oxaliplatin degradation. Sci. Rep. 2017, 7, 4073. [CrossRef] [PubMed]

7. Luo, F.R.; Yen, T.Y.; Wyrick, S.D.; Chaney, S.G. High-performance liquid chromatographic separation of the biotransformation products of oxaliplatin. J. Chromatogr. B Biomed. Sci. Appl. 1999, 724, 345-356. [CrossRef]

8. Allain, P.; Heudi, O.; Cailleux, A.; Le Bouil, A.; Larra, F.; Boisdron-Celle, M.; Gamelin, E. Early biotransformations of oxaliplatin after its intravenous administration to cancer patients. Drug Metab. Dispos. 2000, 28, 1379-1384.

9. Luo, F.R.; Wyrick, S.D.; Chaney, S.G. Biotransformations of oxaliplatin in rat blood in vitro. J. Biochem. Mol. Toxicol. 1999, 13, 159-169. [CrossRef]

10. Jerremalm, E.; Wallin, I.; Ehrsson, H. New insights into the biotransformation and pharmacokinetics of oxaliplatin. J. Pharm. Sci. 2009, 98, 3879-3885. [CrossRef]

11. Graham, M.A.; Lockwood, G.F.; Greenslade, D.; Brienza, S.; Bayssas, M.; Gamelin, E. Clinical pharmacokinetics of oxaliplatin: A critical review. Clin. Cancer Res. 2000, 6, 1205-1218.

12. Reardon, J.T.; Vaisman, A.; Chaney, S.G.; Sancar, A. Efficient nucleotide excision repair of cisplatin, oxaliplatin, and Bis-acetoammine-dichloro-cyclohexylamine-platinum(IV) (JM216) platinum intrastrand DNA diadducts. Cancer Res. 1999, 59, 3968-3971. 
13. Starobova, H.; Vetter, I. Pathophysiology of Chemotherapy-Induced Peripheral Neuropathy. Front. Mol. Neurosci. 2017, 10, 174. [CrossRef] [PubMed]

14. Shirao, K.; Matsumura, Y.; Yamada, Y.; Muro, K.; Gotoh, M.; Boku, N.; Ohtsu, A.; Nagashima, F.; Sano, Y.; Mutoh, M.; et al. Phase I study of single-dose oxaliplatin in Japanese patients with malignant tumors. Jpn. J. Clin. Oncol. 2006, 36, 295-300. [CrossRef] [PubMed]

15. Kern, W.; Braess, J.; Böttger, B.; Kaufmann, C.C.; Hiddemann, W.; Schleyer, E. Oxaliplatin pharmacokinetics during a four-hour infusion. Clin. Cancer Res. 1999, 5, 761-765. [PubMed]

16. Kweekel, D.M.; Gelderblom, H.; Guchelaar, H.J. Pharmacology of oxaliplatin and the use of pharmacogenomics to individualize therapy. Cancer Treat. Rev. 2005, 31, 90-105. [CrossRef]

17. Shord, S.S.; Bernard, S.A.; Lindley, C.; Blodgett, A.; Mehta, V.; Churchel, M.A.; Poole, M.; Pescatore, S.L.; Luo, F.R.; Chaney, S.G. Oxaliplatin biotransformation and pharmacokinetics: A pilot study to determine the possible relationship to neurotoxicity. Anticancer Res. 2002, 22, 2301-2309.

18. Falta, T.; Koellensperger, G.; Standler, A.; Buchberger, W.; Mader, R.M.; Hann, S. Quantification of cisplatin, carboplatin, and oxaliplatin in spiked human plasma samples by ICP-SFMS and hydrophilic interaction liquid chromatography (HILIC) combined with ICP-MS detector. J. Anal. At. Spectrom. 2009, 24, 1336-1342. [CrossRef]

19. Hearnden, V.; Sankar, V.; Hull, K.; Juras, D.V.; Greenberg, M.; Kerr, A.R.; Lockhart, P.B.; Patton, L.L.; Porter, S.; Thornhill, M.H. New developments and opportunities in oral mucosal drug delivery for local and systemic disease. Adv. Drug Deliv. Rev. 2012, 64, 16-28. [CrossRef]

20. Kulkarni, U.; Mahalingam, R.; Pather, S.I.; Li, X.; Jasti, B. Porcine buccal mucosa as an in vitro model: Relative contribution of epithelium and connective tissue as permeability barriers. J. Pharm. Sci. 2009, 98, 471-483. [CrossRef]

21. Matos, B.N.; Pereira, M.N.; Bravo, M.O.; Cunha-Filho, M.; Saldanha-Araújo, F.; Gratieri, T.; Gelfuso, G.M. Chitosan nanoparticles loading oxaliplatin as a mucoadhesive topical treatment of oral tumors: Iontophoresis further enhances drug delivery ex vivo. Int. J. Biol. Macromol. 2020, 154, 1265-1275. [CrossRef]

22. Ito, H.; Yamaguchi, H.; Fujikawa, A.; Tanaka, N.; Furugen, A.; Miyamori, K.; Takahashi, N.; Ogura, J.; Kobayashi, M.; Yamada, T.; et al. A full validated hydrophilic interaction liquid chromatography-tandem mass spectrometric method for the quantification of oxaliplatin in human plasma ultrafiltrates. J. Pharm. Biomed. Anal. 2012, 71, 99-103. [CrossRef]

23. Zhang, W.; Seymour, L.; Chen, E.X. Determination of intact oxaliplatin in human plasma using high performance liquid chromatography-tandem mass spectrometry. J. Chromatogr. B Analyt. Technol. Biomed. Life Sci. 2008, 876, 277-282. [CrossRef]

24. FDA. Draft Guidance for Industry: Bioanalytical Method Validation; US Department of Health and Human Services, Food and Drug Administration, Center for Drug Evaluation and Research (CDER): Washington, DC, USA, 2018.

25. Bastian, G.; Barrail, A.; Urien, S. Population pharmacokinetics of oxaliplatin in patients with metastatic cancer. Anticancer Drugs 2003, 14, 817-824. [CrossRef] [PubMed]

26. Nikanjam, M.; Stewart, C.F.; Takimoto, C.H.; Synold, T.W.; Beaty, O.; Fouladi, M.; Capparelli, E.V. Population pharmacokinetic analysis of oxaliplatin in adults and children identifies important covariates for dosing. Cancer Chemother. Pharmacol. 2015, 75, 495-503. [CrossRef] [PubMed]

27. Ito, Y.; Kobuchi, S.; Shimizu, R.; Katsuyama, Y. Pharmacokinetic and toxicodynamic evaluation of oxaliplatin-induced neuropathy and hematological toxicity in rats. Cancer Chemother. Pharmacol. 2018, 81, 155-161. [CrossRef] [PubMed]

28. Hanada, K.; Suda, M.; Kanai, N.; Ogata, H. Pharmacokinetics and toxicodynamics of oxaliplatin in rats: Application of a toxicity factor to explain differences in the nephrotoxicity and myelosuppression induced by oxaliplatin and the other platinum antitumor derivatives. Pharm. Res. 2010, 27, 1893-1899. [CrossRef]

29. Gao, X.; Wu, L.; Tsai, R.Y.L.; Ma, J.; Liu, X.; Chow, D.S.; Liang, D.; Xie, H. Pharmacokinetic Model Analysis of Supralingual, Oral and Intravenous Deliveries of Mycophenolic Acid. Pharmaceutics 2021, 13, 574. [CrossRef]

30. De Araujo, D.R.; Padula, C.; Cereda, C.M.S.; Tofoli, G.R.; Brito, R.B.; de Paula, E.; Nicoli, S.; Santi, P. Bioadhesive Films Containing Benzocaine: Correlation Between In Vitro Permeation and In Vivo Local Anesthetic Effect. Pharm. Res. 2010, 27, 1677-1686. [CrossRef]

31. Donnelly, R.F.; McCarron, P.A.; Lightowler, J.M.; Woolfson, A.D. Bioadhesive patch-based delivery of 5-aminolevulinic acid to the nail for photodynamic therapy of onychomycosis. J. Control. Release 2005, 103, 381-392. [CrossRef]

32. Donnelly, R.F.; Ma, L.W.; Juzenas, P.; Iani, V.; McCarron, P.A.; Woolfson, A.D.; Moan, J. Topical bioadhesive patch systems enhance selectivity of protoporphyrin IX accumulation. Photochem. Photobiol. 2006, 82, 670-675. [CrossRef]

33. Nussinovitch, A.; Gal, A.; Padula, C.; Santi, P. Physical characterization of a new skin bioadhesive film. Aaps Pharmscitech 2008, 9, 458-463. [CrossRef]

34. Peppas, N.A.; Sahlin, J.J. Hydrogels as mucoadhesive and bioadhesive materials: A review. Biomaterials 1996, $17,1553-1561$. [CrossRef]

35. Vasir, J. Bioadhesive microspheres as a controlled drug delivery system. Int. J. Pharm. 2003, 255, 13-32. [CrossRef]

36. Salman, S.; Bendel, D.; Lee, T.C.; Templeton, D.; Davis, T.M. Pharmacokinetics of a novel sublingual spray formulation of the antimalarial drug artemether in healthy adults. Antimicrob. Agents Chemother. 2015, 59, 3197-3207. [CrossRef] [PubMed]

37. Parikh, N.; Goskonda, V.; Chavan, A.; Dillaha, L. Single-dose pharmacokinetics of fentanyl sublingual spray and oral transmucosal fentanyl citrate in healthy volunteers: A randomized crossover study. Clin. Ther. 2013, 35, 236-243. [CrossRef] [PubMed] 
38. Boddupalli, B.M.; Mohammed, Z.N.; Nath, R.A.; Banji, D. Mucoadhesive drug delivery system: An overview. J. Adv. Pharm. Technol. Res. 2010, 1, 381-387. [CrossRef]

39. Paderni, C.; Compilato, D.; Giannola, L.I.; Campisi, G. Oral local drug delivery and new perspectives in oral drug formulation. Oral. Surg. Oral. Med. Oral. Pathol. Oral. Radiol. 2012, 114, e25-e34. [CrossRef] [PubMed]

40. Patel, V.F.; Liu, F.; Brown, M.B. Advances in oral transmucosal drug delivery. J. Control. Release 2011, 153, 106-116. [CrossRef]

41. Palmer, D.; Levina, M.; Nokhodchi, A.; Douroumis, D.; Farrell, T.; Rajabi-Siahboomi, A. The influence of sodium carboxymethylcellulose on drug release from polyethylene oxide extended release matrices. AAPS PharmSciTech 2011, 12, 862-871. [CrossRef]

42. EMA. Guideline on Bioanalytical Method Validation; European Medicines Agency: Amsterdam, The Netherlands, 2012 ; pp. 1-23.

43. Gabrielsson, J.; Weiner, D. Non-compartmental analysis. Methods Mol. Biol. 2012, 929, 377-389. [CrossRef] 